\title{
Mitigation of Power Quality Problems Using Custom Power Devices: A Review
}

\author{
Miska Prasad*, Ashok Kumar Akella \\ National Institute of Technology, Jamshedpur, India \\ e-mail: 2013pgphdee05@nitjsr.ac.in
}

\begin{abstract}
Electrical power quality (EPQ) in distribution systems is a critical issue for commercial, industrial and residential applications. The new concept of advanced power electronic based Custom Power Devices (CPDs) mainly distributed static synchronous compensator (D-STATCOM), dynamic voltage restorer (DVR) and unified power quality conditioner (UPQC) have been developed due to lacking the performance of traditional compensating devices to minimize power quality disturbances. This paper presents a comprehensive review on D-STATCOM, DVR and UPQC to solve the electrical power quality problems of the distribution networks. This is intended to present a broad overview of the various possible DSTATCOM, DVR and UPQC configurations for single-phase (two wire) and three-phase (three-wire and four-wire) networks and control strategies for the compensation of various power quality disturbances. Apart from this, comprehensive explanation, comparison, and discussion on D-STATCOM, DVR, and UPQC are presented. This paper is aimed to explore a broad prospective on the status of D-STATCOMs, $D V R s$, and UPQCs to researchers, engineers and the community dealing with the power quality enhancement. A classified list of some latest research publications on the topic is also appended for a quick reference.
\end{abstract}

Keywords: power quality, voltage sag, voltage swell, distributed static compensator, voltage source inverter, Z-source inverter, current source inverter, DVR, UPQC

\section{Introduction}

Nowadays electrical power quality is a very important issue in the electrical distribution system. It has been always a challenging task to maintain the power quality within acceptable levels [1-11]. In general, power quality disturbances that affect the voltage and current waveforms quality are imbalances, harmonics, flickers, voltage sags and swells [12-17]. PQ problems can lead to poor power quality which may occur because of increased losses, undesirable and abnormal nature of equipment, problem of interference etc [18-21].

To develop dynamic, flexible and adjustable solution to the electrical power quality disturbances, passive L-C filters [22-24], active power filters (APFs) [25-29], hybrid filters [30] and custom power devices (CPDs) [31-36] are used from time to time.

This paper focuses on a DSTATCOM, DVR and UPQC type compensating custom power devices. The CPDs mainly DSTATCOMs, DVRs and UPQCs are the APF family members connected in shunt, series and a combination of shunt and series to achieve superior control over different power quality disturbances simultaneously.

This paper is intended to present a comprehensive survey of previous research on DSTATCOM, DVR and UPQC type custom power devices for power quality enhancement in power distribution network. Over 200 publications [11-218] are seriously reviewed to classify them in different categories.

The D-STATOM, DVR and UPQC type custom power device are categorized based on the (1) type of converter topology (voltage source converter and current source converter); (2) supply system (single-phase two-wire, three-phase three-wire and four-wire).

Therefore, this paper is presented as follows: The state of the art of D-STATCOM, DVR and UPQC are presented in section 2, section 3 illustrates the classification of custom power devices (D-STATCOM, DVR and UPQC). Section 4 describes the control methodologies and approaches including the derivation of reference signal and current/voltage control techniques. Section 5, latest trends and technical consideration on CPDs are discussed; finally, section 6 discusses the conclusion part of the paper. 


\section{DSTATCOM, DVR and UPQC: State Of The Art}

Electrical power quality (EPQ) problems are an issue that is becoming increasingly important to all levels of usage such as industrial, commercial and utilities. The power quality issues include short-term events such as voltage sags, swells or even transients with duration of less than a few seconds. Power system harmonic and flicker issues also fall into the category of power quality $(\mathrm{PQ})$, even though these issues tend to occur much longer intervals than sags and transients [11]. Table 1 shows the various power quality problems and their causes. The authors [12-16] discussed voltage sag and its characteristics in detail. M.R.Alam et al. [17] proposed an algorithm for detection; classification and characterization of voltage sag and swell in electricity networks, using three-phase voltage ellipse parameters. The proposed method employs the instantaneous magnitude of three-phase voltage signals in three axes, which are separated from each other by $120^{\circ}$.

From time to time different efforts have been carried out to provide an active and flexible solution to mitigate power quality disturbances. Before the advent of active filters, passive filters based on inductors and capacitors [22-24] were used and still used in many power transmission and distribution applications, but it has various disadvantages such as instability, fixed compensation, resonance with supply as well as loads and utility.

To overcome these drawbacks active power filters (APFs) have been used [25-29]. However, they are costly options for power quality enhancement because their ratings are sometimes very close to full load (up to $80 \%$ ) in typical applications.

To face the power quality problems and increase the reliability, an advanced power electronic based devices have launched over last decades. These power electronic based devices are called Custom power devices (CPDs) [31-36]. N.G. Hingorani [7] introduced the concept of custom power. Custom power solution can be network reconfiguration type or compensation type as shown in Figure1. In this paper, a comprehensive review of compensating type is presented [9]. The compensating custom power devices are used for active filtering, load balancing, voltage regulating (sag/swell), harmonic elimination and power factor correction. These devices are either connected in shunt or in series or a combination of both and also called D-STATCOM, DVR and UPQC.

D-STATCOM: D-STATCOM is the most important solid state shunt connected CPD. It has been widely used to precisely regulate system voltage, improve voltage profile, reduce voltage harmonics, reduce transient voltage disturbances and load compensation. D-STATCOM controller can be constructed based on both voltage source inverter topology and current source inverter (CSI) topology [11], [20], [37], [38] as shown in Figure 1. In practice, CSI topology is not used for D-STATCOM because higher losses on the DC reactor of CSI compared to the DC capacitor of VSI [39]. The authors [40], [41] proposed reverse blocking insulated gate bipolar transistor has eradicated the need for the series diode and making CSI a good alternative. The principal of generating instantaneous active and reactive powers by DSTATCOM is shown in Figure 2. In Figure 2, voltages and currents are represented with instantaneous space vectors obtained using a power invariant Clarks transformation. Figure 3 are presented in three cases: the general one, for reactive power equal to zero and for active power equal to zero. Form the Figure 3 it is clear that by generating an appropriate AC voltage it is possible to generate arbitrary instantaneous vectors of both active and reactive power. [11] The authors in [37], [42-44], [45-47] discuss the various aspects such as modeling, design and simulation for reactive power compensation, unbalanced and harmonic compensation and voltage regulation (sag/swell). In [9], [48], a D-STATCOM model is used for feasibility and validating the design. K.R. Padiyar [10], H. Fugita et al. [49], Arya et al. [50] discussed DSTATCOM for voltage regulation in detail. 

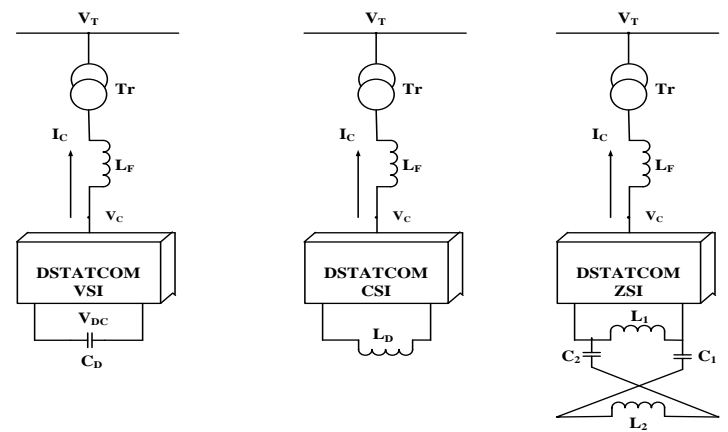

Figure 1. Schematic Diagram of VSI, CSI and ZSI based DSTATCOM

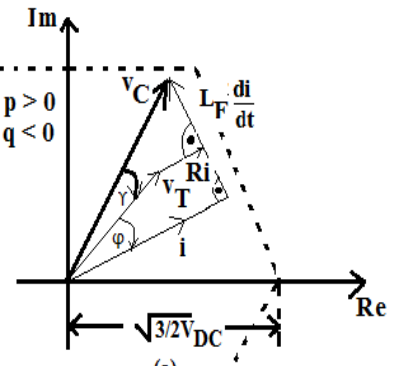

(a)

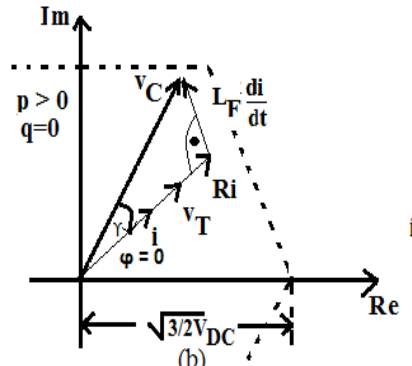

(b)

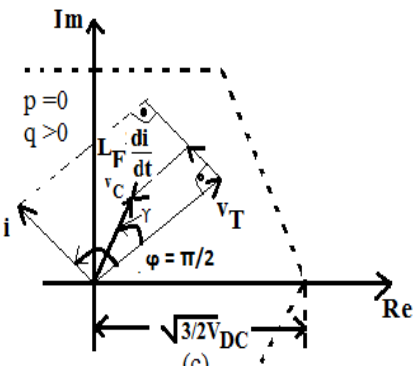

(c)

Figure 2. Operating Principle of DSTATCOM (a) General Case (b) Reactive Power Zero and (c) Active Power Zero

DVR: A dynamic voltage restorer (DVR) is a power electronic (PE) converter-based CPD, which can protect sensitive loads from all supply-side disturbances other than outages. It is connected in series with a distribution feeder as shown in Figure. 3 and also is capable of generating or absorbing real and reactive power at its $A C$ terminals. The basic principle of a DVR is simple: by inserting a voltage of the required magnitude and frequency, the DVR can restore the load-side voltage up to the desired amplitude and waveform even when the source voltage is either unbalanced or distorted [11]. A typical location in the distribution system and the operating of the DVR is shown in Figure.3. The different aspects such as modeling, design and simulation for harmonic elimination, voltage flicker suspension [9], voltage sag and swell mitigation are reported in [51-54]. A.K.Jindal et al. [55] highlighted dynamic voltage restorer for voltage regulation function.

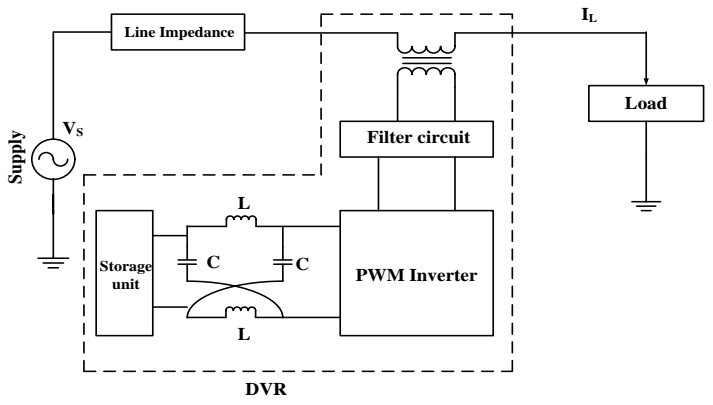

Figure 3. Basic Structure of DVR

UPQC: For enhancing power quality in the system and protecting sensitive loads a universal solution can use by an integration of the series-parallel active power filters called UPQC as depicted in Figure 4.UPQC is a flexible device that can compensate almost all types 
of $P Q$ disturbances related to voltage and current simultaneously. Shunt active power filter is the most promising to tackle the current-related problems such as current harmonics, current unbalance, reactive current whereas, the series APF is the most suitable to overcome the voltage-related problems such as voltage harmonics, voltage unbalance, voltage flicker, voltage sag and swell.

In operating principal, UPQC is a union of shunt and series APFs with two VSI-based common self-supporting DC bus. The shunt APF is controlled in a current controlled mode such that it produces a current that is equal to the set of the reference current as produced by the control algorithm of UPQC.

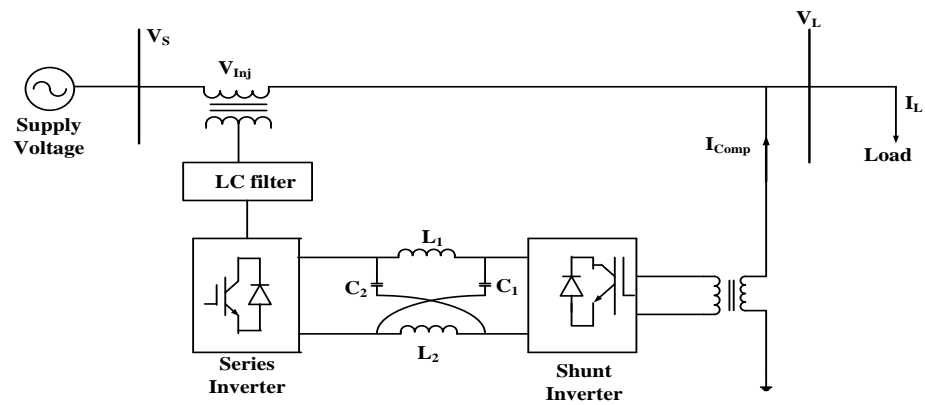

Figure 4. Schematic Diagram of UPQC

$$
\mathrm{i}_{\mathrm{Sh}}(\omega \mathrm{t})=\mathrm{i}_{\mathrm{S}}^{*}(\omega \mathrm{t})-\mathrm{i}_{\mathrm{L}}(\omega \mathrm{t})
$$

where $i_{s h}(\omega t), i_{S}^{*}(\omega t), i_{L}(w t)$ represents the shunt APF current, reference source current and load current. Shunt active power filter should inject a current to eliminate the harmonics produced by a nonlinear load.

The series active power filter is controlled in voltage control mode such that it generates a voltage and injects in series with line to achieve a sinusoidal and distortion free voltage at the load terminal. In the case of voltage sag (VS) condition, series APF should inject a voltage to maintain the load voltage.

$$
\mathrm{V}_{\mathrm{Sc}}(\omega \mathrm{t})=\mathrm{V}_{\mathrm{L}}^{*}(\omega \mathrm{t})-\mathrm{V}_{\mathrm{S}}(\omega \mathrm{t})
$$

where $V_{S c}(\omega t), V_{L}^{*}(\omega t), V_{S}(\omega t)$ represents the series APF voltage, reference load voltage and source voltage. The system modeling aspects of the UPQC are reported in [56-63]. In [64], a mathematical modeling and design of a versatile UPQC are discussed clearly. A.Ghosh et al. [65] discussed the application of UPQC for voltage regulation in critical loads.

\begin{tabular}{|c|c|c|c|c|c|}
\hline \multirow{2}{*}{$\begin{array}{c}\text { Broad } \\
\text { Classification }\end{array}$} & \multirow{2}{*}{$\begin{array}{c}\text { Specific } \\
\text { Classification }\end{array}$} & \multicolumn{2}{|c|}{ Typical Characteristics } & \multirow[t]{2}{*}{ Disturbance } & \multirow[t]{2}{*}{ Consequence } \\
\hline & & Duration & Magnitude & & \\
\hline 1. Transients & 1.1 Impulsive & $50 \mathrm{~ns}-1 \mathrm{~ms}$ & $<6 \mathrm{kV}$ & & $\begin{array}{c}\text { Insulation failure. } \\
\text { Reduced Lifetime of } \\
\text { transformers and motors }\end{array}$ \\
\hline & 1.2 Oscillatory & $5 \mu \mathrm{s}-0.3 \mathrm{~ms}$ & $0-4 \mathrm{pu}$ & & \\
\hline $\begin{array}{l}\text { 2.Short } \\
\text { duration }\end{array}$ & 2.1. Interruption & $10 \mathrm{~ms}-3 \mathrm{~min}$ & & & Disconnection. \\
\hline variations & 2.2. Sag & $10 \mathrm{~ms}-1 \mathrm{~min}$ & $1-90 \%$ & & $\begin{array}{l}\text { Disconnection of } \\
\text { sensitive loads. Fail } \\
\text { functions. }\end{array}$ \\
\hline
\end{tabular}

Table 1. Some Effects of Power Quality Problems for the Different Voltage Events

IJEEI Vol. 5, No. 3, September 2017: $207-235$ 
2.3. Swell

3. Long

variations

4. Curve distortion

5. Voltage

Unbalance

6. Voltage

Fluctuation
$10 \mathrm{~ms}-1 \mathrm{~min} \quad 110-180 \%$
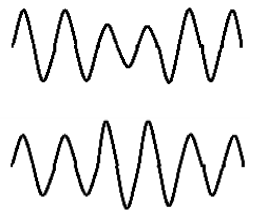

3.1 Under Voltage $\quad>1 \mathrm{~min}$

$>1 \mathrm{~min}$

$80-90 \%$

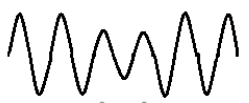

3.2 Over Voltage

$160-120 \%$

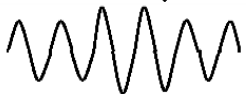

$0-20 \%$

Stationary

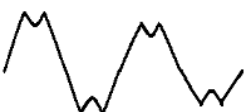

Extended heating. Fail function of electronic equipment

Voltage quality for overloaded phase. Over load and noise from 3phase equipment.

Ageing of insulation. Fail function. flicker

\section{Classification of Custom Power Devices (D-STATCOM, DVR AND UPQC)}

In this section, classification of compensating type custom power devices is given. As shown in Figure.5, a pictorial view for the classification of custom power devices. The custom power devices are mainly classified in two main categories: (1) based on converter topology and (2) based on supply system.

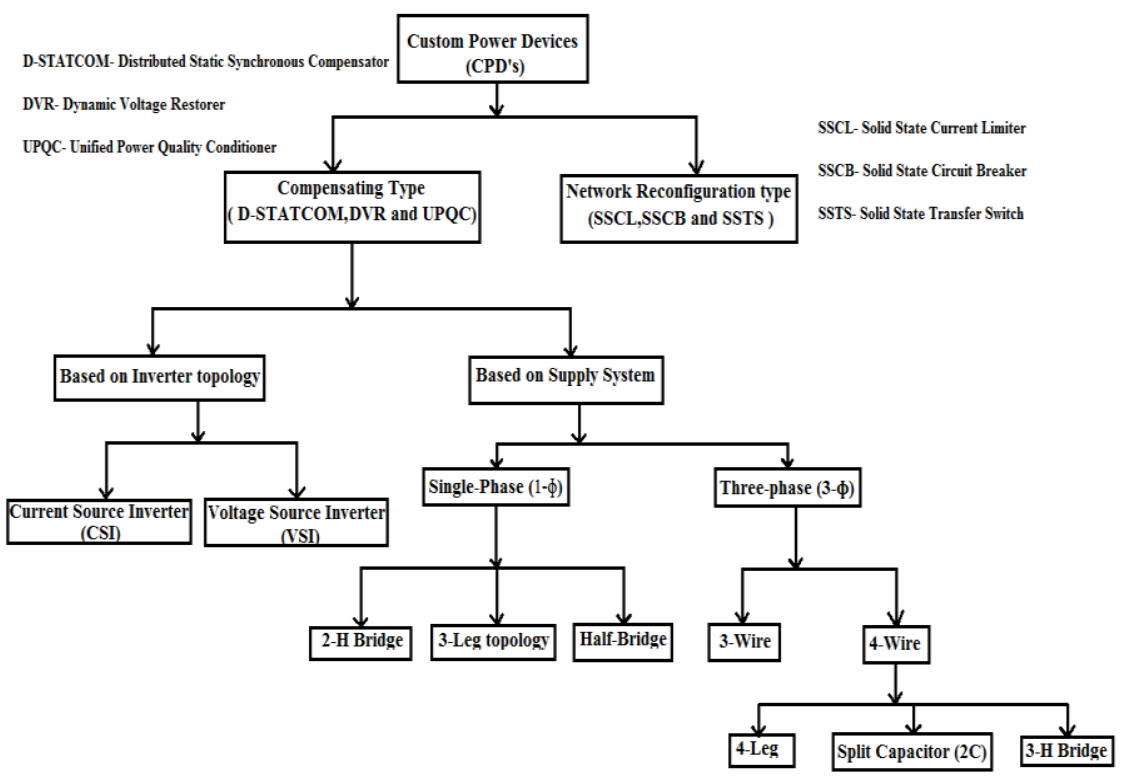

Figure 5. Classifications of CPDs 


\subsection{Based on Converter Topology}

This D-STATCOM, DVR and UPQC type custom power devices can be constructed based on voltage source inverter (VSI) topology, current source inverter (CSI) topology [11] and Z-source inverter topologies.

Figure 6 (a-c) depicts single-line representation of a CSI based D-STATCOM, DVR and UPQC system configuration [18], [20], [21]. The D-STATCOM, DVR and UPQC may be constructed using a pulse width modulated (PWM) current source inverter (CSI) [27], [28], [3741], [66-70] which uses an inductor LDC as a common energy storage to form the DC link. In practice, D-STATCOM, DVR and UPQC based on current source inverter are not used due to high cost, higher losses, [20], [39], and also it cannot find its application in multilevel configurations. The second topology is based on VSI, which is the most common and popular inverter topology can be used in D-STATCOM, DVR and UPQC system configurations [9], [2026], [29- 36], [42-65], [70-218].

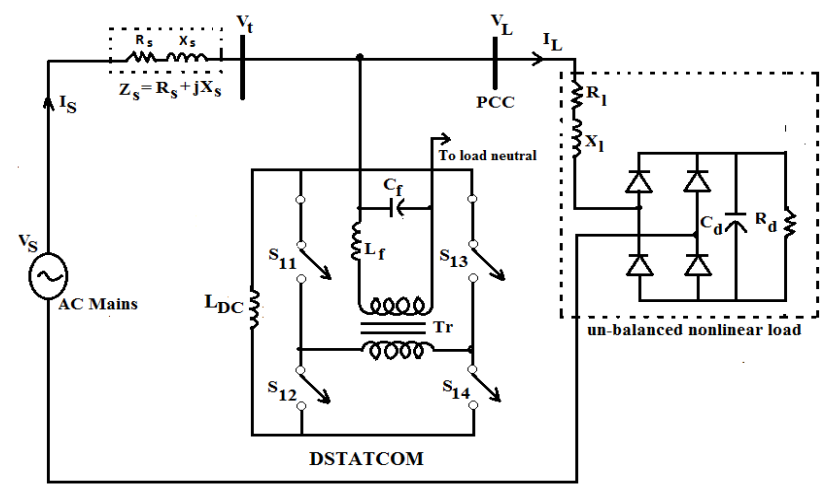

(a)

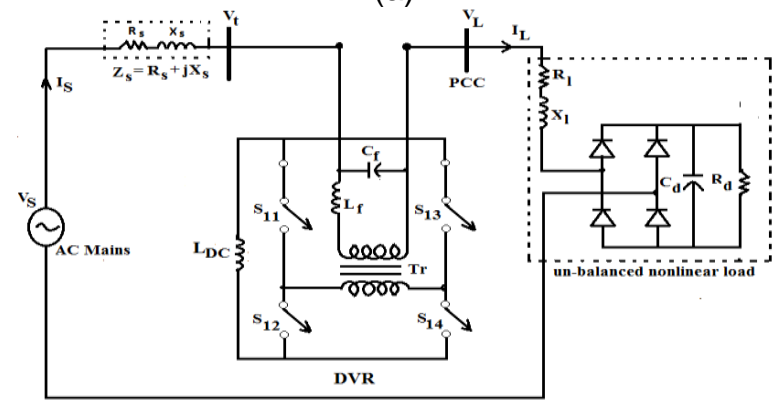

(b)

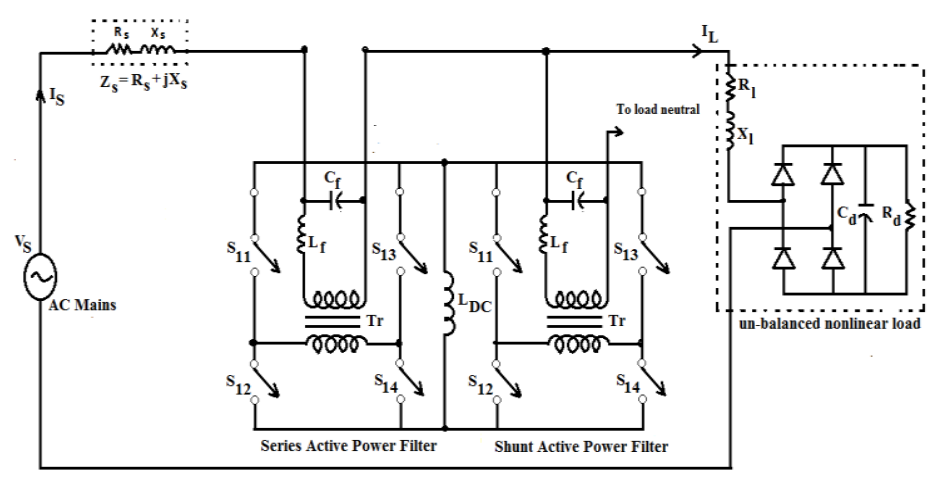

(c)

Figure 6. CSI-Based (a) DSTATCOM (b) DVR and (c) UPQC 
Figure 7(a-c) shows the configurations of D-STATCOM, DVR and UPQC based on voltage source inverter (VSI) and Figure $8(\mathrm{a}-\mathrm{c})$ shows the Z-source inverter based configurations.

The VSI-based topology has the advantages over CSI-based topology include cheaper, flexible overall control, no need of blocking diodes and capable of multilevel operation [18]. A.Ghosh et al. [9] explained a CSI is usually more reliable and fault tolerant than a VSC because the large series inductor limits the rate of rise of current in the event of a fault. However, CSIs have higher losses because of the need to store energy by circulating current in the inductors which are lossier than capacitive energy storage. Since capacitors are more efficient, smaller and less expensive than inductors, VSIs are most commonly used in DSTATCOM, DVR and UPQC system configurations.

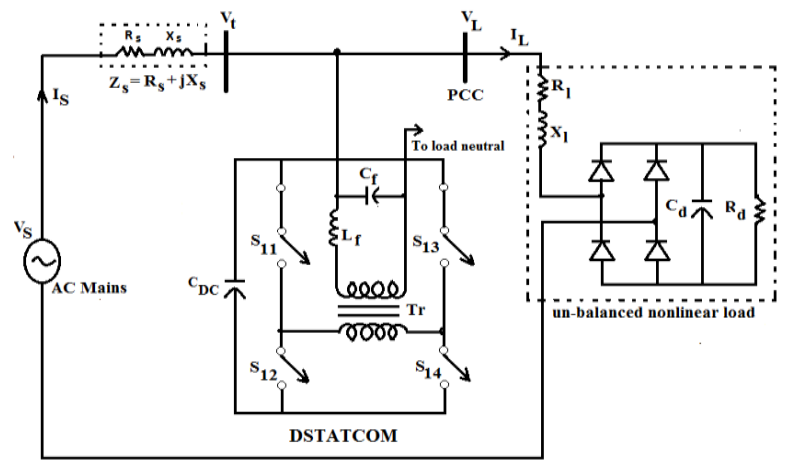

(a)

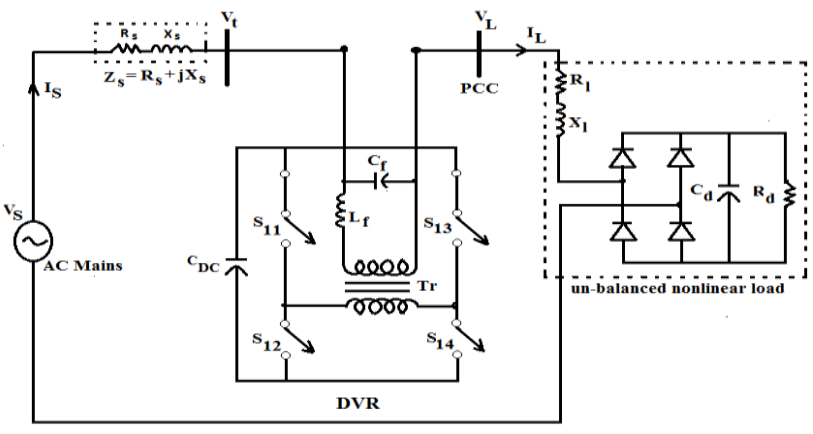

(b)

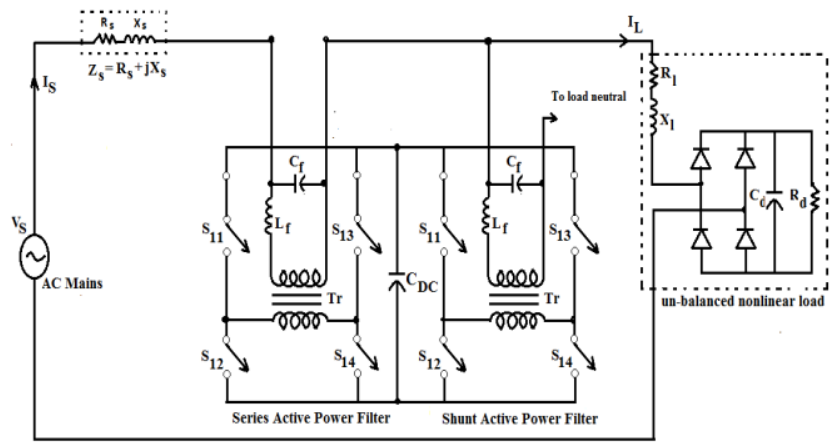

(c)

Figure 7. VSI-Based (a) DSTATCOM (b) DVR and (c) UPQC 


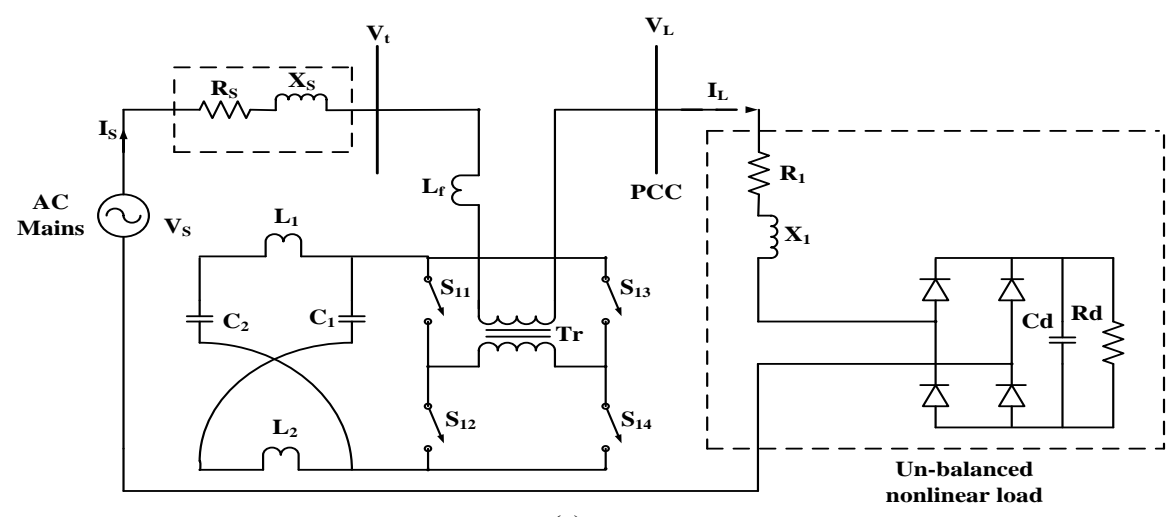

(a)
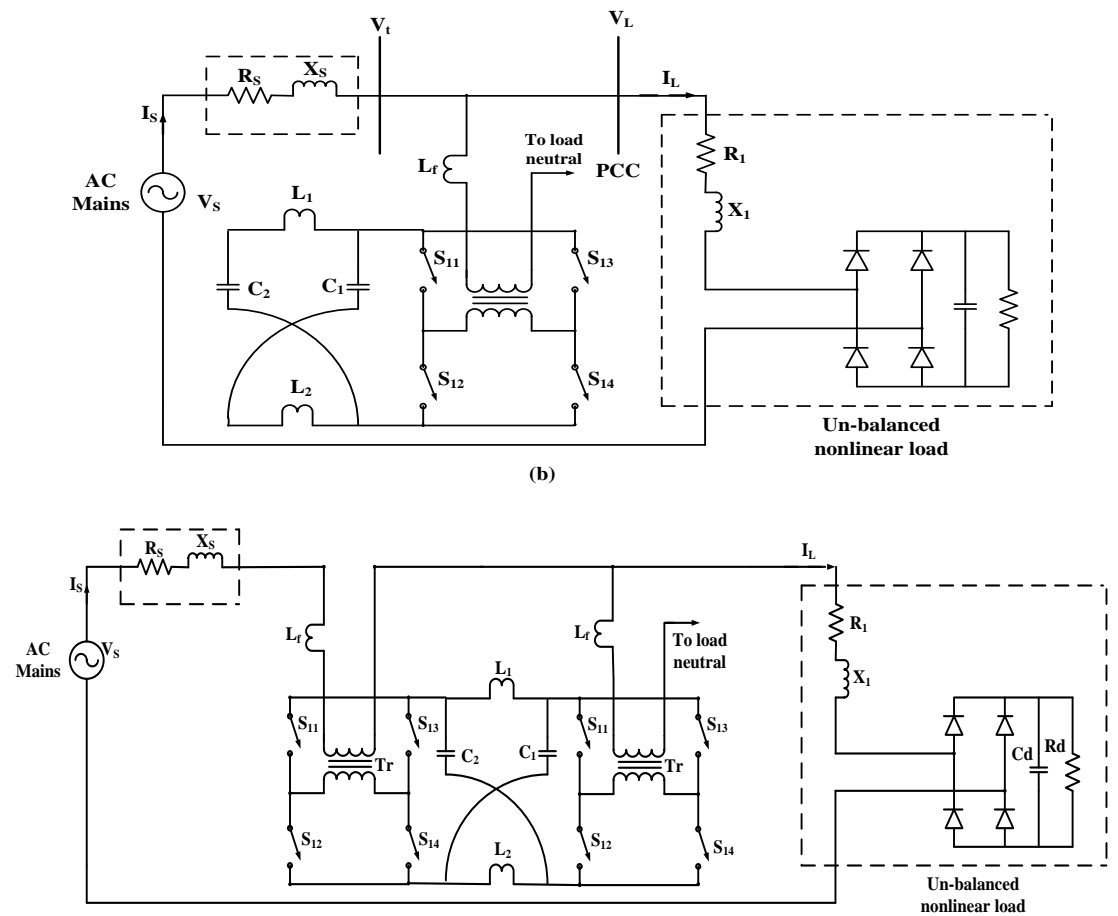

(c)

Figure 8. ZSI-Based (a) DVR (b) DSTATCOM and (c) UPQC

\subsection{Based On Supply System}

To mitigate the power quality disturbances in power distribution system different $D$ STATCOM, DVR and UPQC configurations are introduced and they can be divided based on the type of the supply system topology. In general, AC supplies or loads on the power system can be mainly classified into single-phase two-wire (1p2w) and three-phase three-wire (3p3w) and four-wire $(3 p 4 w)$ source. The supply voltage related power quality problems have similar characteristics for single-phase and three-phase systems. In addition, three-phase systems need voltage unbalance compensation capability to provide enhanced power quality (PQ). The load current harmonics and reactive current are the major limitations for a single-phase system. For the case of three-phase three-wire $(3 p 3 w)$, one must need to consider current unbalance apart from the reactive and harmonics current.

\subsubsection{Single-phase two wire (1p2w) compensating devices}

Single-phase two-wire (1p2w) systems are used in all three modes as shunt (DSTATCOM) [71-74], series DVR [75-83] and a union of both as UPQC [84-101]. 
Figure 9 (a-c) shows the most popular DSTATCOM, DVR and UPQC configurations consist of two H-bridge inverters [72-74], [83], [84], [86- 97], [99], [101] in single-phase two-wire $(1 \mathrm{p} 2 \mathrm{w})$ system to compensate the power quality (PQ) issues by injecting current in case of $D$ STATCOM, voltage in case of DVR and both in the case of UPQC of the electrical power distribution system.

Figure 10(a-c) shows the most commonly used D-STATCOM, DVR and UPQC configuration to consists of 3-leg inverters [102] in single-phase two-wire (1p2w) system to mitigate the power quality (PQ) disturbances by injecting current, voltage and both current and voltage.

Figure 11(a-c) depicts the most popularly use D-STATCOM, DVR and UPQC system configuration which consists of half-bridge inverters [85], [98], [100], [103] in single-phase twowire (1p2w) system to compensate the power quality (PQ) problems by injecting current in case of D-STATCOM, voltage in case of DVR and both in the case of UPQC of the electrical power distribution system.

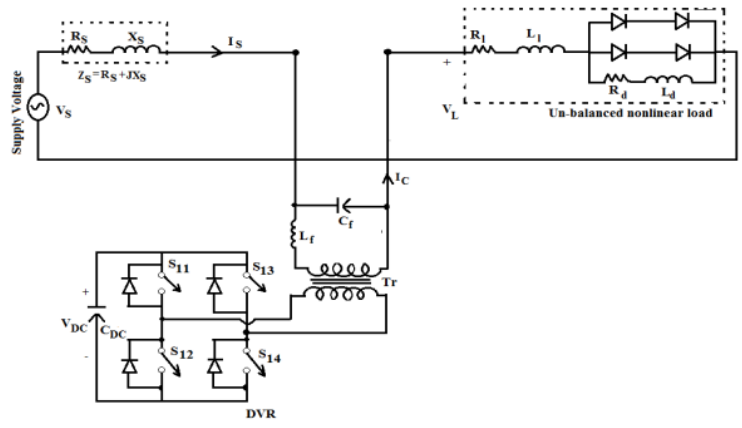

(a)

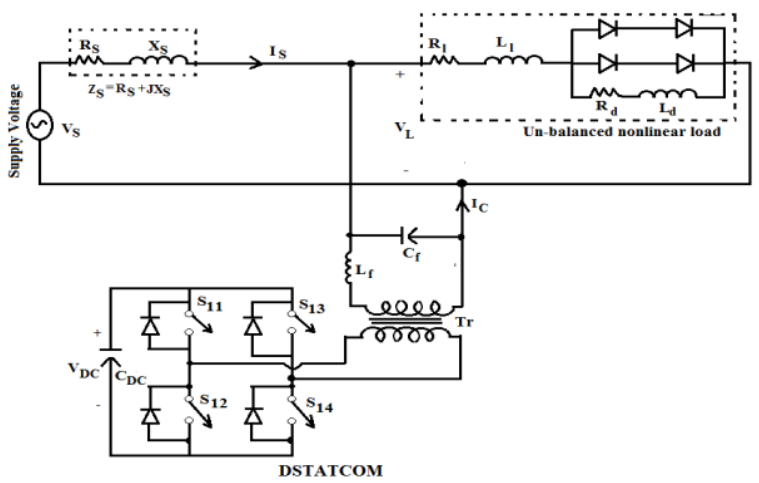

(b)

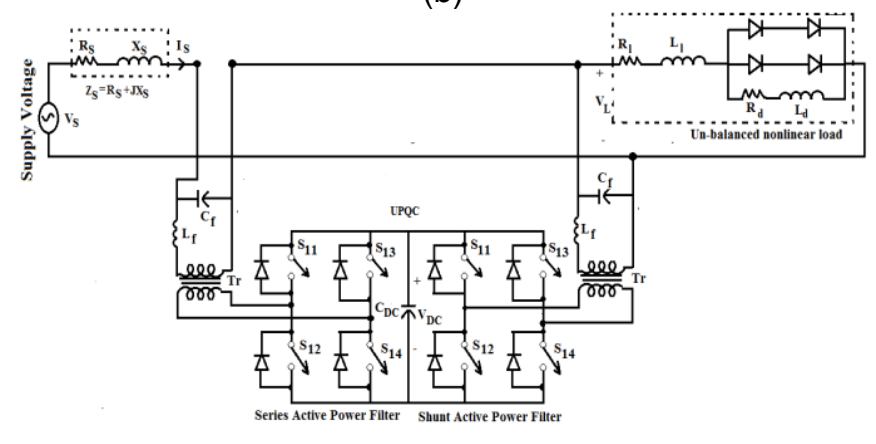

(c)

Figure 9. Two H-bridge (a) DVR (b) DSTATCOM and (c) UPQC 


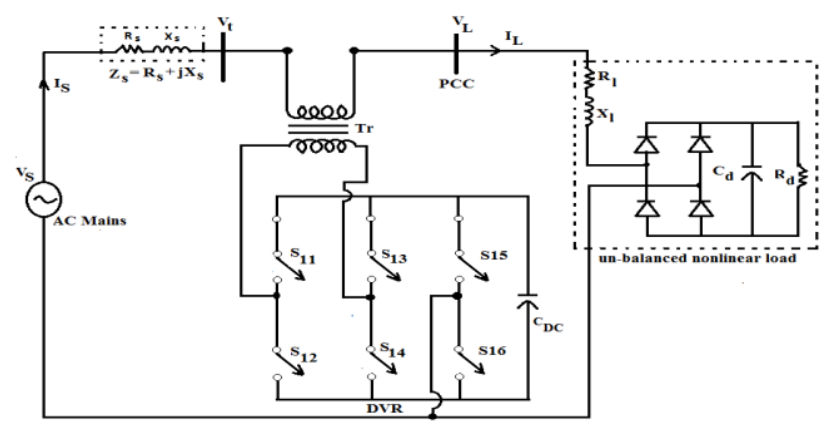

(a)

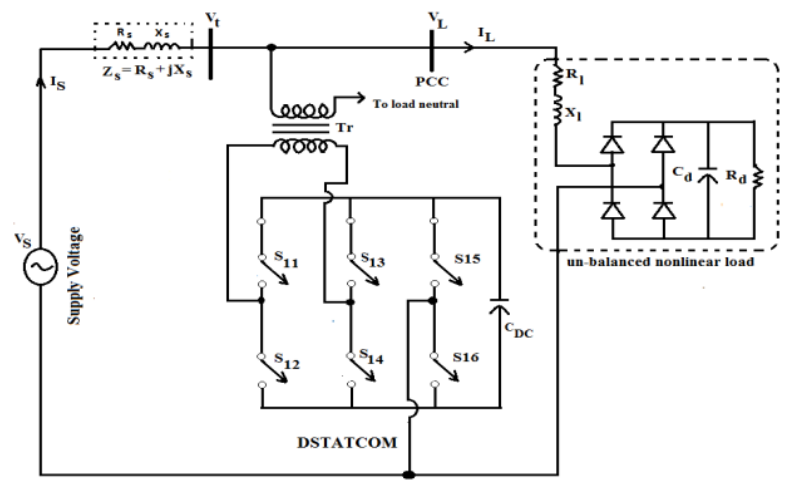

(b)

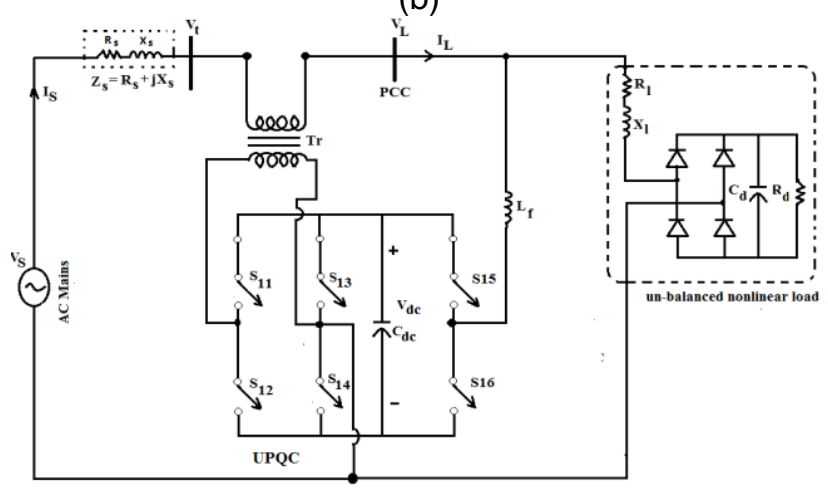

(c)

Figure 10. 3-Leg (a) DVR (b) D-STATCOM and (c) UPQC 


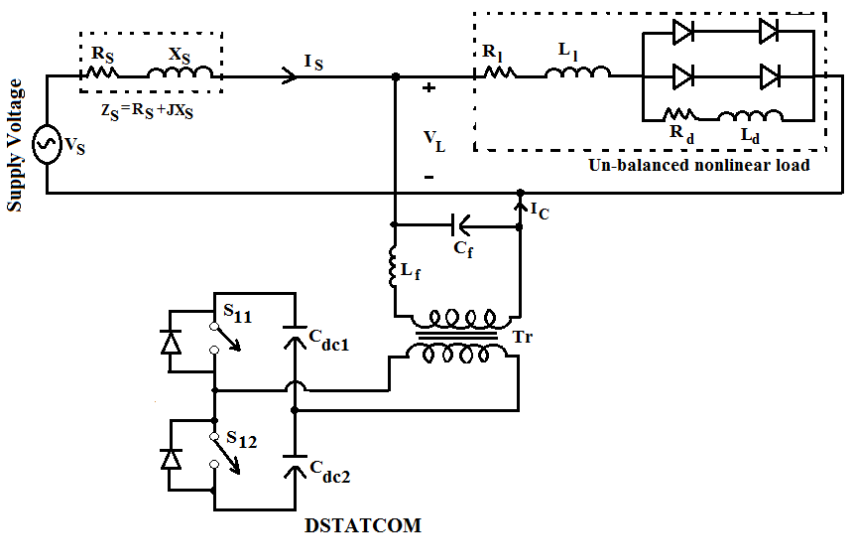

(a)

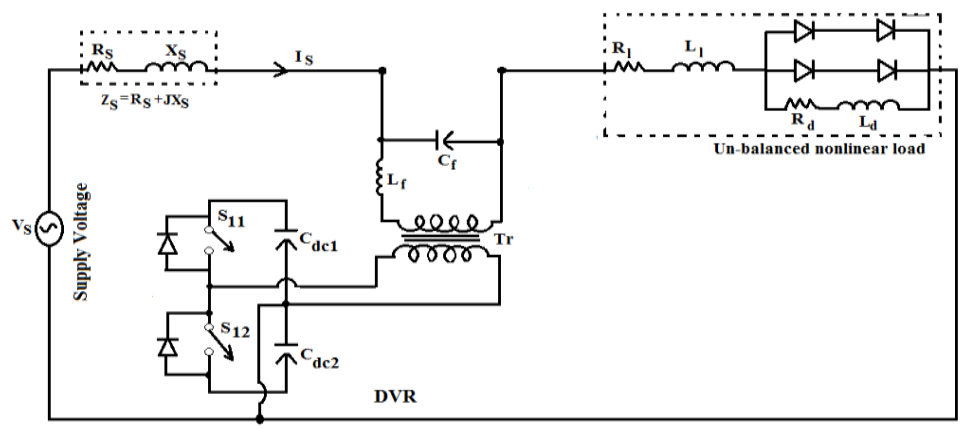

(b)

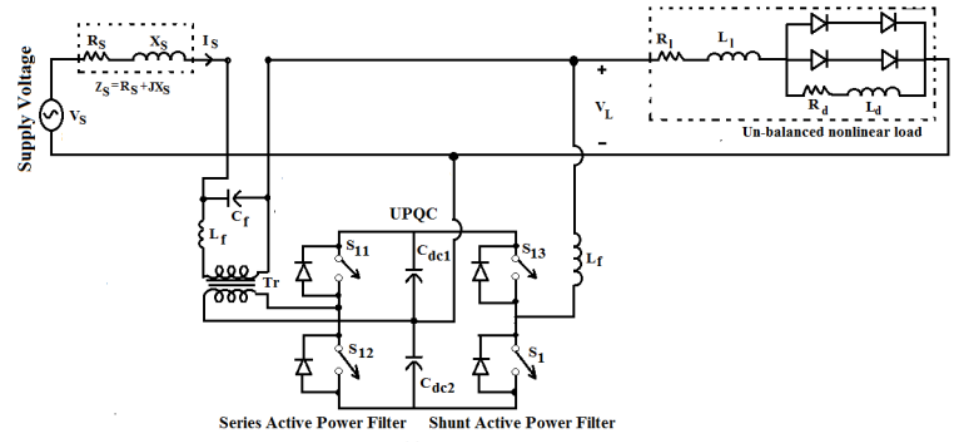

(c)

Figure 11. Half-Bridge (a) DSTATCOM (b) DVR and (c) UPQC

\subsubsection{Three-phase three wire (3P3W) Compensating devices}

Three-phase three-wire (3p3w) nonlinear loads such as adjustable speed drives (ADSs), frequency converter, current regulator, arc welding drives/machines and arc furnace causes several power quality (PQ) problems such as voltage sag, swell, harmonics etc. . Most widely preferred and suitable three-phase three wire (3p3w) voltage source converter (VSC)based D-STATCOM , DVR and UPQC network configurations are shown in Figure 12 (a-c) and are widely reported in literature [56-60], [70],[104-118], [119-130], [131-179]. 


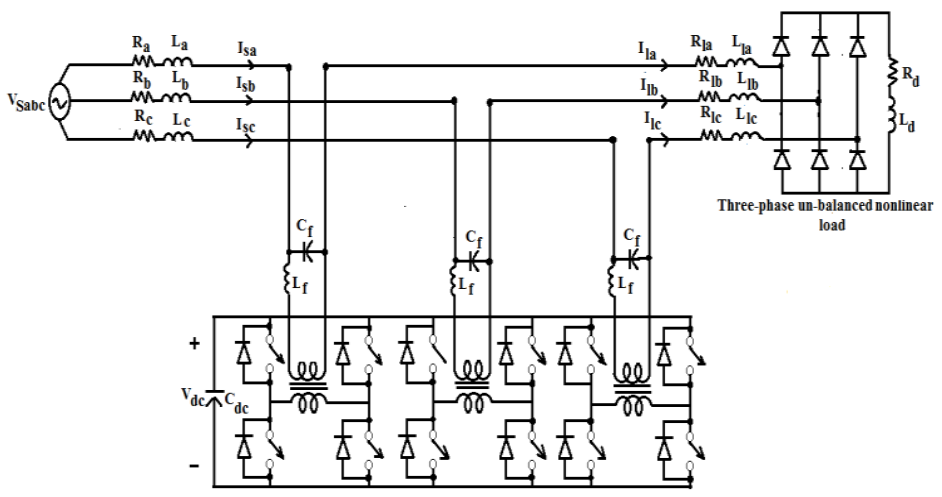

(a)

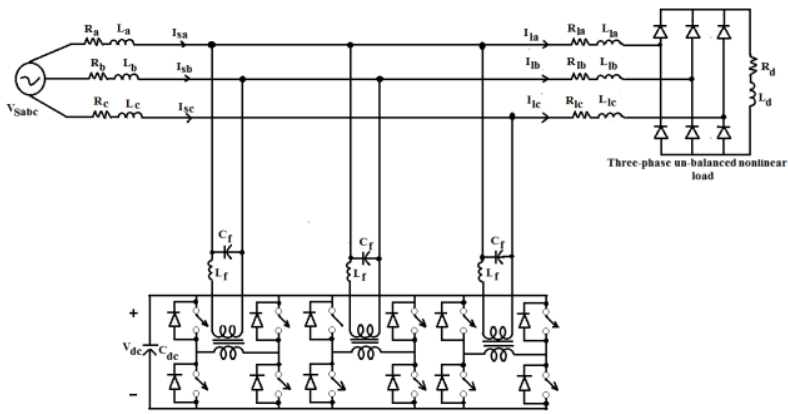

(b)

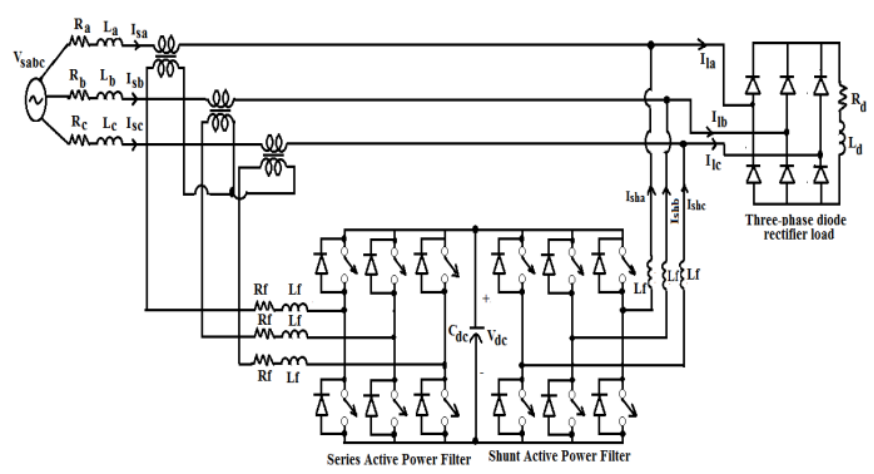

(c)

Figure 12. Three-phase Three-Wire (a) DVR (b) DSTATCOM and (c) UPQC

\subsubsection{Three-phase four-wire (3p4w) compensating devices}

A large number of single-phase (1- $\phi)$ loads may be supplied from three-phase (3- $\phi)$ mains with a neutral conductor. They cause excessive neutral current, harmonics and reactive power burden. To reduce the neutral current in a three-phase four-wire (3p4w) system [180183], various D-STATCOM, DVR and UPQC configurations have been applied, mainly two split capacitor (2C), four-leg (4L ) and three $\mathrm{H}$-bridge (3HB) configurations. The first one uses three $\mathrm{H}$-bridge voltage source converters (VSCs) and these $\mathrm{H}$-bridges are connected through isolation transformers. The split capacitor topology and four-leg topologies are looking similar. The fundamental difference between these two topologies is the number of power semiconductor devices and the connection of the neutral wire. 


\subsubsection{Three $\mathrm{H}$-bridge topology}

Figure 13 a-c shows the three-phase four-wire (3p4w) D-STATCOM, DVR and UPQC system configuration based on three $\mathrm{H}$-bridge $(3 \mathrm{HB})$ topologies in three-phase four wire distribution system and are reported in [65],[184-193]. Three H-bridge (3HB) topology consists of three single-phase (1- $\phi) \mathrm{H}$-bridge (full bridge) voltage source inverter (VSI) tied with a common self supporting DC bus [194]. The main advantage of this topology is the control can be done either as a three-phase (3- $\phi)$ unit or three separate single-phase $(1-\phi)$ units. The maximum voltage that appears across each $\mathrm{H}$-bridge is the single phase voltage and not the three-phase voltage as in the case of capacitor midpoint or four-leg topology.

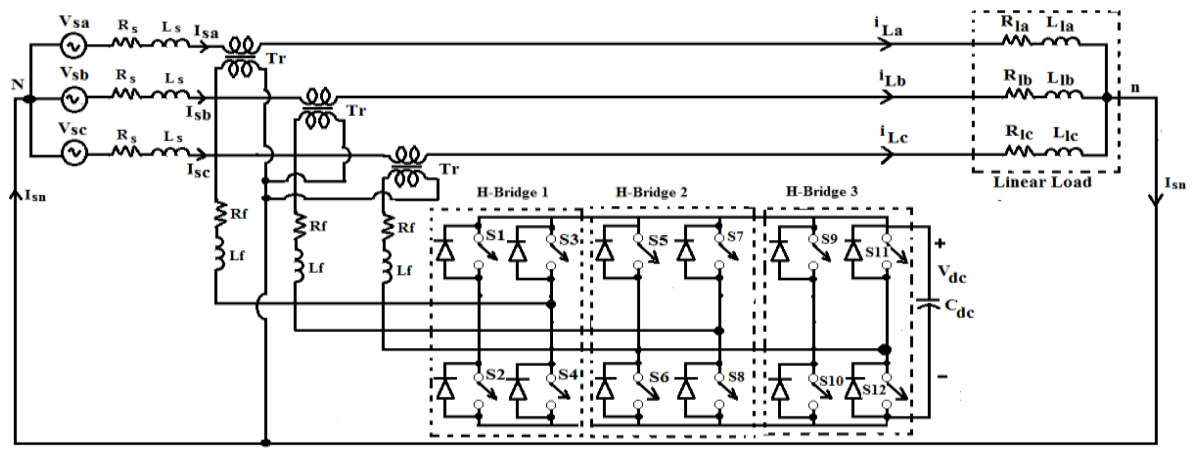

(a)

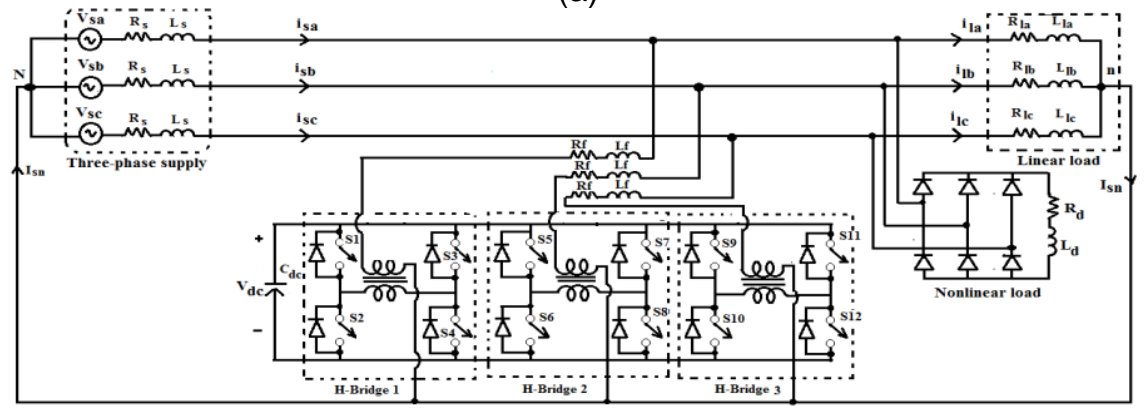

(b)

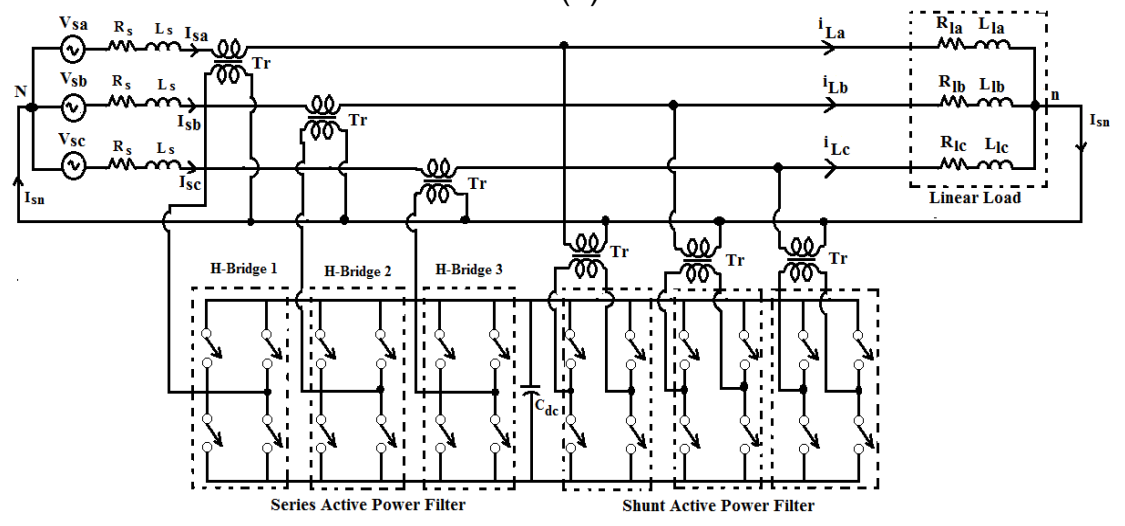

(c)

Figure 13. Three-Phase Four-Wire Three H-bridge (a) DVR (b) DSTATCOM and (c) UPQC

\subsubsection{Three-phase four-wire split capacitor (2C) topology}

The split capacitor topology uses the standard three-phase traditional inverter where the DC capacitor is split and the neutral wire is directly connected to the electrical mid-point of the capacitors through an inductance. The capacitors midpoint allows load neutral current to flow 
through one of the DC capacitors Cd-1, Cd-2 and return to the AC neutral wire. Figure 14 (a-c) shows the 3p4w D-STATCOM, DVR and UPQC system configuration based on split capacitor topology [195-208]. In this topology, the voltage unbalance between the capacitors is one of the series problems [18], [20], [209]. This is due to the direct flow of neutral current through one of the capacitors $(\mathrm{Cd}-1, \mathrm{Cd}-2)$, causes voltage variations among them. There are two possible ways to balance the capacitors: (1) by adjusting the switching of the inverter [209], but this approach requires additional control circuitry and (2) by using additional power electronic switching circuitry, but this approach increases the cost.

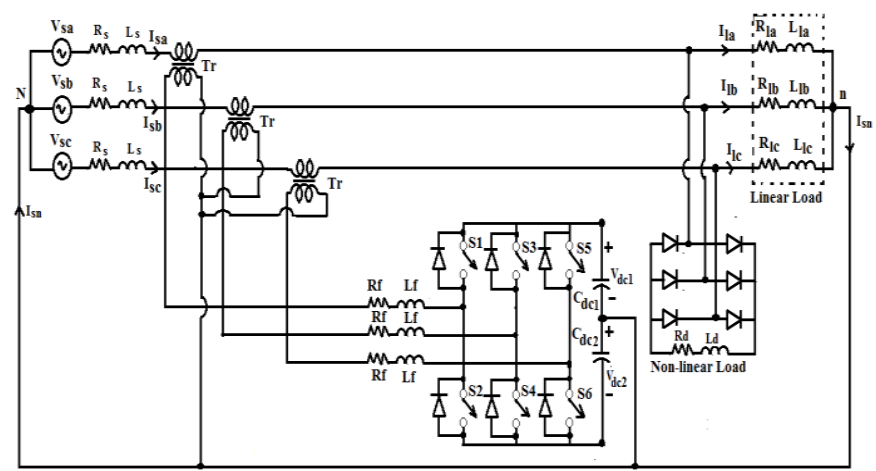

(a)

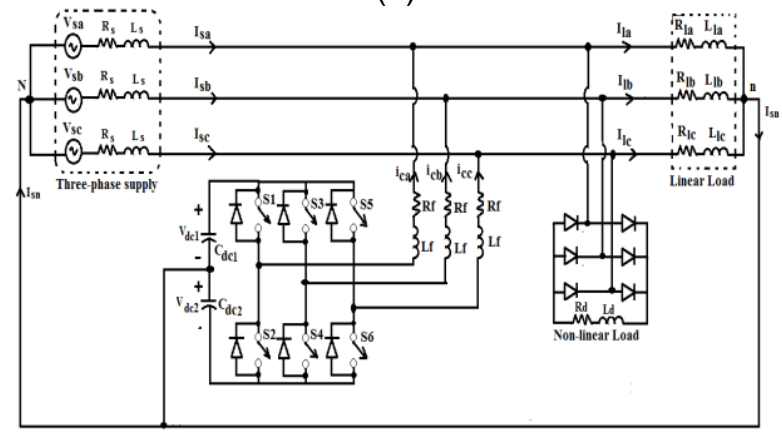

(b)

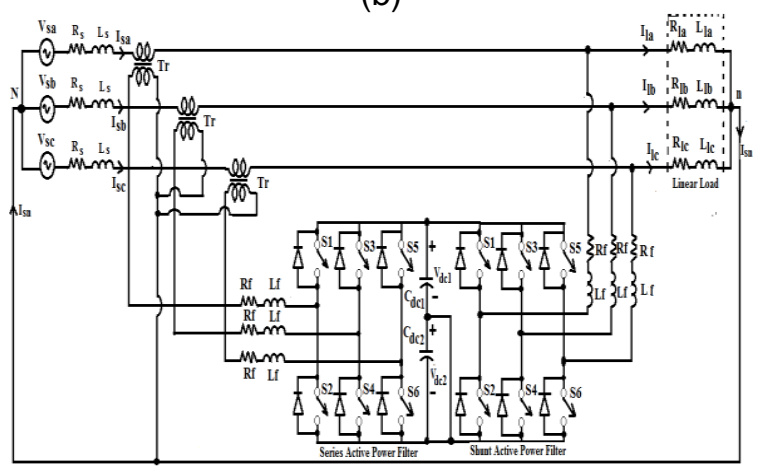

(c)

Figure 14. Three-phase Four-Wire Split Capacitor (a) DVR (b) DSTATCOM and (c) UPQC

\subsubsection{Three-phase four-wire $(3 p 4 w)$ four-leg $(4 L)$ topology}

Figure 15 a-c shows the 3p4w D-STATCOM, DVR and UPQC system configuration based on three phase four-wire $(3 p 4 w)$ four-leg (4-L) topology. For elimination of high neutral currents the 4-leg topology used in 3P4W systems [27], [210-218]. Having a higher number of switching devices this topology outweighed the split capacitor topology by number for factors [27], [209]: (a) Better controllability: In 4- leg topology only one DC-bus voltage needs to be 
regulated. This importantly simplifies the control circuitry with better controllability [27]. (b) Lower DC voltage and current requirement: This topology requires a lower DC-bus voltage and current with it. (c) Higher order harmonics in DC side current: In this topology, the DC side current has only higher order harmonics and will not contribute to significant ripple on the DC-bus voltage.

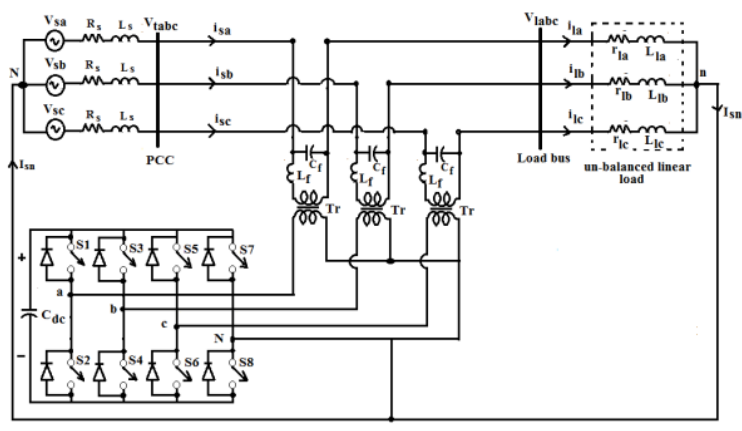

(a)

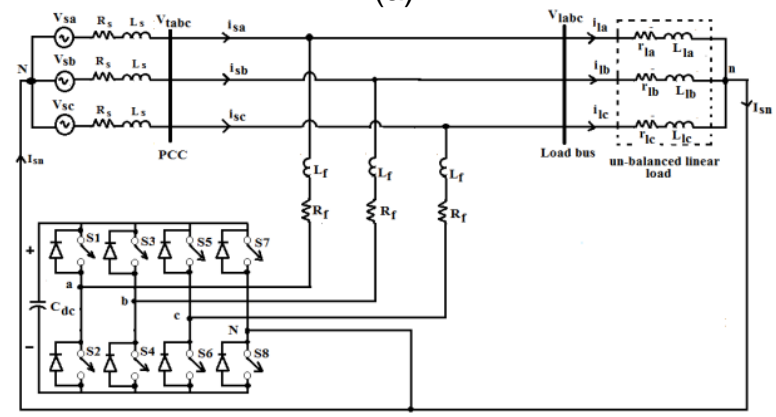

(b)

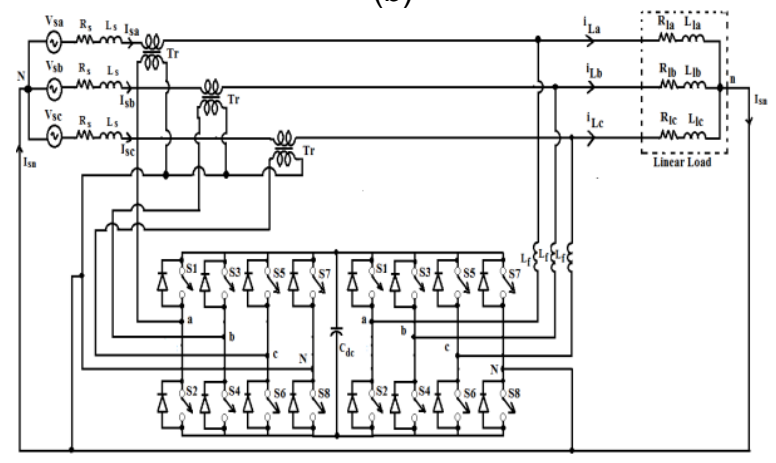

(c)

Figure 15. Three-Phase Four-Wire Four-Leg (4L) (a) DVR (b) DSTATCOM and (c) UPQC

\section{Control Techniques for Custom Power Devices (D-STATCOM, DVR and UPQC)}

The election of strategy control is essential to get the desired compensation aim. Control technique is the heart of the D-STATCOM, DVR and UPQC devices. It plays the most important role in overall performance in any power electronics based system. The control of custom power devices (DSTATCOM, DVR and UPQC) is realized in three stages. In the first stage, the necessary current and voltage signals are sensed to gather accurate system information. In the second stage compensating signals in terms of current and voltage levels are produced based on different control methods and DSTATCOM, DVR and UPQC configurations. In the third stage of control, the gating signals for the solid state devices of the compensating devices are derived either in the open loop or closed loop. The open and closed loop schemes are used only for lower order systems. For second and higher order systems sliding mode 
control, linear quadratic regulator (LQR), pole-shift control, deadbeat control, and Kalman filter are used. Recently, for improving the dynamic and steady state performance of the devices, the complex algorithms like fuzzy logic [46], [82], [108], [115], [125], [161], [163], neural networks and genetic are implemented with the help of microprocessor and microcontroller

\subsection{Derivation of Reference Signal}

Generation of reference signals either in terms of voltage, current and both are important part of custom power devices (D-STATCOM, DVR and UPQC) for their control, transient as well as steady-state performance. The performance of the D-STATCOM, DVR and UPQC are strictly depends on its reference signal production technique. In general, control strategies to generate compensation or reference signals are based on frequency domain and time domain correction techniques [9] as shown in figure 16. In addition, to these control methods for power electronic based compensating type custom power devices (D-STATCOM, DVR and UPQC) can also be categorized on the basis of linear and nonlinear, classical and modern, hard and soft computing, online and off-line, but for the sake of brevity, they are not discussed here.

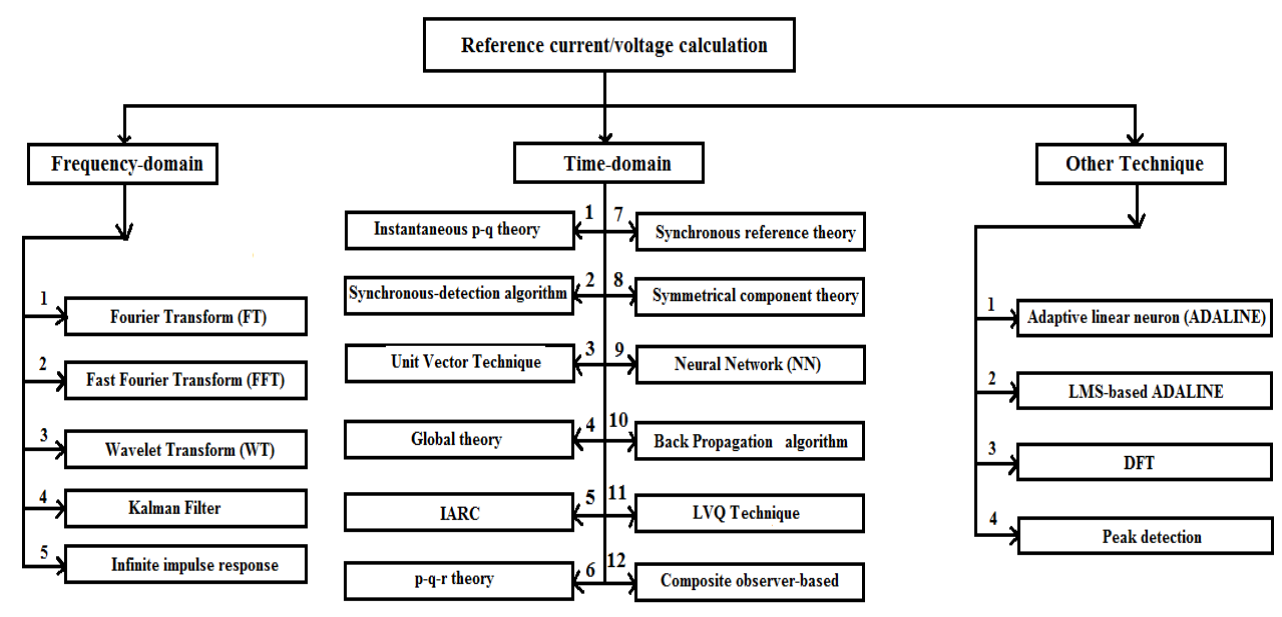

Figure 16. Reference Signal Derivation

\subsubsection{Compensation in Frequency-Domain Technique}

The most commonly used model in the frequency-domain (FD) [9] is a balanced threephase $(3 \phi)$ system at fundamental and harmonic frequency and single-phase (1- $\phi)$ system. They are mainly divided into Fourier transform, Wavelet transform, infinite impulse response and Kalman filter.

\subsubsection{Fourier Transform (FT)}

One of old techniques used in analysis of non-sinusoidal signals is Fourier transform. Fourier analysis has been used for power quality assessment for a long period. It permits mapping of signals from time domain to frequency domain and vice-versa by decomposing the signals into several frequency components. Application of Discrete FT and fast Fourier transform (FFT) are very useful to overcome some of the disadvantages of the earlier one [18], [20], [21], [27], [28]. In custom power devices (D-STATCOM, DVR, and UPQC) FFT is used to extract the harmonic components from the harmonic polluted signals. Due to excessive computation in online application, FFT has high response time.

\subsubsection{Wavelet Transform (WT)}

Fourier transform fails in the analysis of transients owing to the non-sinusoidal property, Wavelet transforms (WT) helps us in such cases. Wavelet transform analysis [18], [20], [21] has been suggested as a new tool for measurement and monitoring power quality problems both in

IJEEI Vol. 5, No. 3, September 2017 : $207-235$ 
absence and presence of transients [5], [9], [11], [18], [20],[21],[53],[133],[218]. Fourier transform or Wavelet transform is a cumbersome computation and results in a large response time. Hence, this makes it difficult for real -time application with dynamically varying loads [21].

\subsubsection{Kalman Filtering method}

For detection and analysis of voltage events (voltage sag and swell) in distribution system Kalman filter have been used. The Kalman filtering method gives the information on both magnitude and phase angle of the supply voltage during the voltage sag and swell events and the point-on-wave where the voltage events begin unlike the RMS method [18], [20], [81], [98], [121], [145], [212].

\subsubsection{Compensation in Time-Domain (TD) Technique}

Control methods for D-STATCOM, DVR and UPQC in the time-domain are based on instantaneous derivation of compensating commands in the form of either voltage, current or both voltage and current signals. There are a large number of control methods in time-domain. Few are briefly discussed here.

\subsubsection{Instantaneous Reactive Power Theory ( $p$-q Theory)}

Akagi introduced the first version of the instantaneous reactive power theory in English. It is also known as $p$-q theory for three-phase $(3-\phi)$ circuits. However, it is only become known worldwide after their second publication (1984). This theory is based on a coordinate's transformation from $a-b-c$ (or 1-2-3) axes to new $\alpha-\beta-0$ axes. The aim of $p-q$ control strategy is to find an effective strategy to compensate nonlinear loads using active power filters. Initially it was applied to balanced three-phase three-wire systems (3p3w) and then it was extended to unbalanced four-wire systems [18], [20], [21], [56], [61], [71], [92], [110], [116], [131], [133], [134], [136], [144], [146], [159], [161], [165], [167], [173], [180-183], [187], [188], [190], [202], [203], [213], [216].

\subsubsection{Synchronous detection theory (SDT)}

The synchronous detection algorithm is very similar to the instantaneous reactive power algorithm and relies in the fact that three-phase currents are balanced. The mean power is calculated and equally divided between the three phases. In synchronization process, the signals are synchronized with respect to the phase voltage for each phase. Implementation of this technique is very easy, but it suffers voltage harmonics [20], [27], [28], [133], [202].

\subsubsection{Cross-vector theory (CVT)}

In cross-vector theory (CVT) Clarks $(\alpha-\beta-0)$ transformation does not necessarily required because, it directly calculates the instantaneous powers in the $a-b-c$ coordinates. Cross-vector theory (CVT) defines one instantaneous real power and three instantaneous imaginary powers by scalar/vector product of the voltage and the current space vectors in a three-phase four wire system. The sum of the instantaneous real and imaginary powers is equal to the instantaneous apparent power and this power is used to maintain the power conversion [20], [181], [182].

\subsubsection{Global theory (GT)}

This theory does not need any kind of reference frame transformation because the reference compensation currents are directly determined in the $a-b-c$ reference frame. Therefore, this theory gives less complexity in realizing the control circuit of the D-STATCOM, DVR and UPQC. Using this theory D-STATCOM, DVR and UPQC are able to compensate reactive power, suppress harmonics and neutral currents of the distorted and unbalanced load without supplying and consuming active power [20], [182], [183].

\subsubsection{Vectorial theory (VT)}

Vectorial theory uses the same power variables as the original instantaneous imaginary power in phase coordinates. This method also does not need any kind of coordinate transformation. The current vector is divided into three components. The first one is collinear with respect the modified voltage vector and it transports the instantaneous active power. The second one is collinear with respect to the zero sequence voltage vector, and it transport the 
instantaneous zero-sequence power and third one is normal with respect to the modified and zero-sequence voltage vectors and it transports the instantaneous reactive power [20], [180], [182].

\subsubsection{6. $p-q-r$ theory}

The instantaneous reactive power theory (IRPT) bear disadvantages of not compensating the load under distorted and unbalanced point of common coupling (PCC) voltages. To overcome these limitations the original $p$-q theory has been modified and generally known as $p-q-r$ theory. The D-STATCOM, DVR and UPQC controllers based on this modified $p$ q-r theory can be found in [18], [20], [21],[113],[119], [180- 182],[188],[192], [205]

\subsubsection{Synchronous Reference Frame (SRF) Theory}

The synchronous reference frame (SRF) theory is developed in time-domain based reference current/voltage generation technique. The SRFT is performing the operation in steady-state or transient state as well as for generic voltage and current and capable of controlling the active power filters in real time system [15] , [18], [20], [21], [27], [28], [51], [54], [57], [58], [76], [77], [82], [104], [106], [111], [115], [120], [121], [125], [127], [128], [130],[131], [133], [134], [137], [141], [142], [150], [153], [155], [160], [167], [177], [178], [179], [180], [182], [187], [189], [190], [195], [204], [203], [207], [213],[214], [217], [218], [219]. One of the important characteristics of this theory is the simplicity of calculation because it involves only algebraic calculation. The undesired AC components are eliminated using low pass filters. The controller mainly deals with DC quantities so the system is stable, but causes a time-delay in filtering the DC quantities.

\subsubsection{Instantaneous symmetrical component (ISC) theory}

A symmetrical component theory is generally a choice in the D-STATCOM, DVR, and UPQC applications to extract the fundamental positive-sequence component when the systems supply voltages are unbalanced and distorted. The ISC theory based control algorithm is capable of providing perfect compensation of any kind of unbalance and harmonics in the load [18], [20]. [21], [65], [105], [109], [126], [136], [137], [182], [184], [188], [195-199], [201], [213].

\subsubsection{Neural Network (NN) based theory}

Neural network (NN) technique can handle efficiently the multi-input multi-out control system. Thus, the artificial neural network technique can be utilized to develop the controller for the D-STATCOM, DVR and UPQC to compensate different voltage and current related power quality problems [53] [68] [108], [115], [138], [150], [220].

\subsubsection{Back Propagation (BP) based theory}

Back propagation control algorithm is used to identification of user faces, industrial processes, data analysis, mapping data, control of power quality improvement custom power devices (D-STATCOM, DVR and UPQC). Bhim Singh et al. [118] proposed a BP algorithm is implemented in three-phase shunt connected power quality improvement device known as $D$ STATCOM. Due to more numbers of learning steps, the training process is slow, but after the training of samples, BP technique generates very fast trained output response [20], [118].

\subsubsection{Learning vector quantization (LVQ) based theory}

Learning vector quantization (LVQ) technique [59], [181] is used to determine the structure of classifier by minimizing the bounds of the trained error and generalization error.

\subsubsection{Other algorithms}

To determine the current and voltage compensating signals there are numerous optimizations and estimated techniques such as adaptive linear neuron (ADALINE), LMS-based ADALINE, differential evolution, Fortescue decomposition with recursive DFT, and peak detection can be used.

\subsection{Current/Voltage Control Techniques}

Generation of suitable gating signal is the most important part of D-STATCOM's, DVR's and UPQC's control technique and has a high influence on the compensation performance [39]. Figure 17 shows the classification of current/voltage control techniques. The current/voltage

IJEEI Vol. 5, No. 3, September 2017: $207-235$ 
control techniques often categorized as feed-forward (open-loop), feed-back (closed-loop) and second and higher order systems.

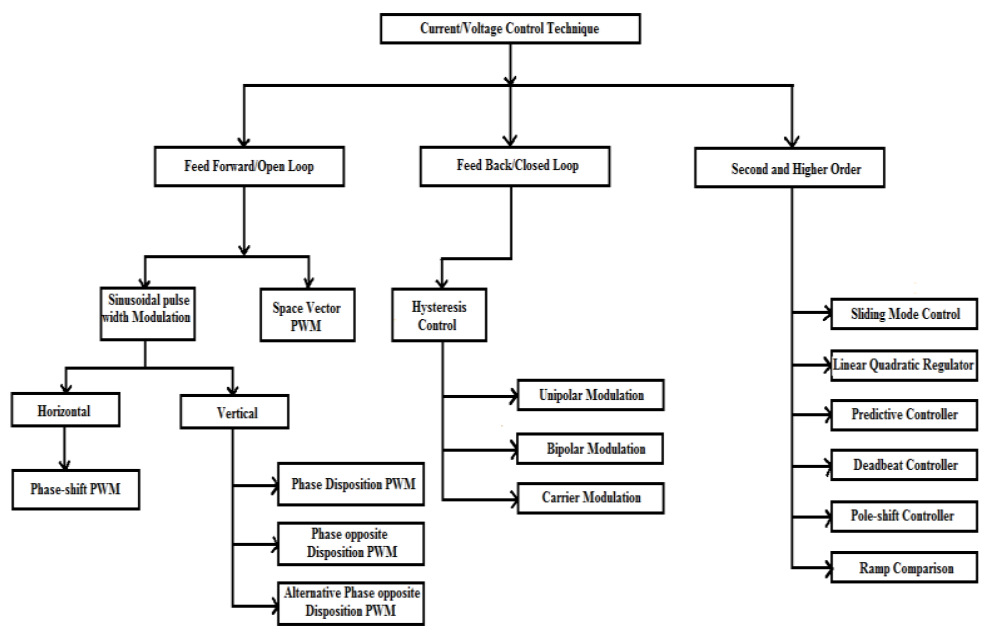

Figure 17. Classifications of Current/Voltage Control Techniques

\subsubsection{Feed forward (Open-loop) methods}

The feed forward method is divided into sinusoidal pulse width modulation (SPWM) and space vector pulse width modulation (SV-PWM) methods.

\subsubsection{Sinusoidal pulse width modulation (SPWM) method}

The most popular form of pulse width modulation (PWM) synthesis is the sinusoidal pulse width modulation (S-PWM) [20], [47], [77], [80-82], [107], [111], [112], [117], [125], [126], [130], [203], [205], [207]. In an S-PWM scheme the modulating signal is sinusoidal and carrier signal is a triangular wave. The magnitude of these two signals is compared to generate firing pulses which in turn is used to control the inverter. To increase the performance of multilevel inverter based D-STATCOM, DVR and UPQC the multicarrier S-PWM control methods are generally used. The multicarrier S-PWM can be categorized according to vertical and horizontal carrier signals typically being triangular wave forms as shown in figure 17. The vertical multicarrier S-PWM techniques can be sub-categorized as (a) Phase- Disposition pulse width modulation (PD-PWM): Phase-disposition pulse width modulation (PD-PWM) technique employs a $(m-1)$ number of carriers which are all in phase accordingly. All eight carrier waves are in phase with each other in nine-level converter [20], [110]. (b) Phase opposition Disposition pulse width modulation (POD-PWM): Phase opposition disposition pulse width modulation (POD-PWM) technique employs an ( $\mathrm{m}-1)$ number of carriers which are all in-phase above and below the zero reference. All eight carrier waves are phase-shifted by $180^{\circ}$ between the ones above and below zero reference in nine-level converter [20], [110]. (c) Alternative Phase Opposite Disposition pulse width modulation (APOD-PWM): This technique requires each of $(\mathrm{m}$ 1) carrier waveform for an m-level phase waveform to be phase displaced from each other by $180^{\circ}$ alternatively [20], [110]. The horizontal multi-carrier SPWM is identified as phase-shifted (PS) control techniques. This technique employs a $(m-1)$ number of carriers, phase-shifted by $90^{\circ}$ accordingly. All eight carrier waves are phase-shifted by $90^{\circ}$ in nine-level converter.

\subsubsection{Space vector pulse width modulation (SV-PWM) method}

Space vector pulse width modulation (SV-PWM) is one of the popular PWM techniques used in multilevel inverters and best among all the PWM methods. In this method eight different switching combinations are possible for a three-phase three-leg (3-L) inverter based DSTATCOM, DVR and UPQC . Six active vectors (V1-V6) form the axes of a hexagon among these eight switching vectors and feed electric power to the load. Two-adjacent zero vectors 
(V0-V7) are located at the origin and do not feed any power to the load [20], [27], [43], [83], [84], [70], [114], [127], [131], [202], [205], [214].

\subsubsection{Feed-back (Closed-loop) methods}

Most custom power devices like D-STATCOM, DVR and UPQC are operated in closed loop fashion in which they either track a specific current reference or a voltage reference or both. The hysteresis controller or bang-bang controller is the most common form of tracking control for lower order closed loop systems.

\subsubsection{Hysteresis controller}

The method of controlling a voltage source inverter (SVI) so that an output current/voltage is generated which follows a reference current/voltage waveform, known as hysteresis current/voltage control. In hysteresis current control, limit bands are set on either side of a signal representing the desired output voltage waveform. The sign reference signal wave of desired magnitude and frequency compared with the actual signal. When the signal cross the prescribed hysteresis upper limit, upper switch is turned OFF and the lower switch is turned ON. Similarly when the signal cross the prescribed lower limit, the lower switch is turned OFF and the upper switch is turned ON. Hysteresis control technique is widely used in the D-STATCOM, DVR and UPQC applications because of its ease of implementation, fast dynamic response and inherent peak current-limiting capability [20], [28], [56], [58], [59], [65],[72], [76], [86], [94], [159] [161], [165], [169], [171], [175], [183], [184], [185], [186], [187], [188], [198], [200], [201], [211], [217].

\subsubsection{Second and higher order systems}

First order systems are readily stabilized by proportional controllers, even when the gain approaches infinity, while many resonant systems become unstable under high proportional control.

\subsubsection{Sliding mode controller (SMC)}

Sliding mode controller (SMC) can be alleviated the need for accurate mathematical models [20], [27], [73], [94], [133]. This controller does not need accurate mathematical model, but requires knowledge of parameter variations to ensure stability. As the power electronic based custom power devices such as DSTATCOM, DVR and UPQC converters are highly variable structured, sliding mode control offers several advantages such as stability even for large supply and load variations, robustness, good dynamic response and simple implementation.

\subsubsection{Linear quadratic regulator (LQR)}

Linear quadratic regulator (LQR) consists of the two weighting matrices one $Q$ and $R$ whose value set by hit and trail method until satisfactory steady-state response with minimum settling time is achieved. Due to presence of wide gain margin (GM) $\left(-60^{\circ}\right.$ to $\left.+\infty\right)$ and phase margin $(\mathrm{PM})\left(-60^{\circ}\right.$ to $\left.+60^{\circ}\right)$ the linear quadratic regulator control ensures the stability of closed system with robustness feature. Another important feature of the LQR is that it can tolerate the input non-linearity [20], [59], [185].

\subsubsection{Predictive and Deadbeat controller}

Predictive and deadbeat method predicts the current error vector on the basis of the actual/present error and the load parameters $(R, L, C)$ at the beginning of each modulation period. The voltage to be generated by pulse width modulation during the next modulation period is determined to minimize the forecast error [20].

\subsubsection{Constant switching frequency predictive algorithm}

In this technique, the predictive algorithm calculates the voltage vector signals once every sampling period. This will force the current vector according to it's signal. The main disadvantage of this algorithm is that it does not guarantee the inverter peak current limit [20]. 


\subsubsection{Deadbeat controllers}

When the choice of the voltage vector is made in order to null the error at the end of the sample period, the predictive controller is called a deadbeat controller [20], [58], [94], [133].

\subsubsection{Pole-shift controller}

This controller produces a variable switching frequency control action and designed in such a way that the desired reference voltage, current and both are tracked accurately. This type of pole-shift control can only be used when the systems state space model is well known. For simplicity, a single phase distribution system is considered for all the system studies, but it can easily be extended to a three-phase distribution system [9], [20], [187].

\section{Technical and Economical Consideration}

The use of D-STATCOM, DVR and UPQC type CPD's to improve electrical power quality is reported since mid 1990s [34]. CPD's mainly D-STATCOM, DVR and UPQC have been developed with high performance, more functionalities and low costs. To reduced rating and enhance performance of CPD's efforts have been made for optimize the control, energy saving, reduced parts, reduced switching losses, minimum power injection, and selective harmonic elimination. The control techniques applied to DSTATCOM's, DVR's and UPQC's will play most important role to alleviate/mitigate the $P Q$ problems. So optimizing the control techniques and executing multifunctional control are the main research trend. The CPD's provide maximum amount of real power to the load is a deciding factor in determining the capability of the device. The selection of D-STATCOM, DVR and UPQC structure for practical applications is most significant task for scientists and engineers. The main design considerations for proper selection of CPDs are: manufacturing cost level, current and voltage distortion level, dv/dt stress level, power rating and output voltage level.

\section{Conclusion}

A comprehensive review and discussion on the D-STATCOMs DVRs and UPQC's to enhance the electrical power quality at utility grid has been reported in this paper. The extensive review and classification of topologies/configurations and control techniques of compensating type CPDs provide compensating solution to different $P Q$ disturbances. With the required features, customers can select a particular compensating device (D-STATCOM, DVR and UPQC). This exhaustive review on DSTATCOM, DVR and UPQC will be useful reference guide to the users, manufacturers and researchers working in the field of $P Q$ improvement using CPDs.

\section{Acknowledgement}

The authors are thankful to government of India. One of the authors M. Prasad is thankful to All Indian Council of Technical Education (AICTE), Ministry of Human Resources Development (MHRD), and Government of India for providing financial assistance to do the research work under Technical Quality Improvement Programme (TEQIP).

\section{References}

[1] RC Dugan, MF McGranaghan, HW Beaty. Electrical Power Systems Quality. New York: McGraw-Hill. 1996.

[2] Sankaran C. Power quality. Florida: CRC Press. 2002)

[3] IEEE Recommended Practices and Requirements for Harmonic Control, Electrical Power Systems, IEEE Standard.1992.

[4] IEEE Standard for Interconnecting Distributed Resources with Electric Power Systems. IEEE Standard. 1547-2003, 2003.

[5] Surajit Chattopodhyay, Madhuchhanda Mitra, Samarjit Sengupta. Electric Power Quality. London: New York. 2011.

[6] Edwald F.Fuchs, Mohammad A.S.Masoum. Power Quality in Power Systems and Electrical Machines. Perth. 2008.

[7] NG Hingorani, L Gyugyi. Understanding FACTS: Concepts and Technology of Flexible AC Transmission Systems. Institute of Electrical and Electronics. Engineers, 2000. 
[8] VK Sood. HVDC and FACTS Controllers-Applications of Static Converters in Power Systems. Boston: Kluwer. 2004.

[9] A Ghosh, G Ledwich. Power Quality Enhancement Using Custom Power Devices. Boston: Kluwer. 2002.

[10] KR Padiyar. FACTS Controllers in Transmission and Distribution. New Delhi: New Age International. 2007.

[11] A Moreno-Munoz. Power Quality Mitigation Techniques in a Distribution Environment. London. 2007

[12] V Barrera Núñez, J Meléndez Frigola, S Herraiz Jaramillo. A servey on voltage sag events in power systems. Transmission \& Distribution Conf., Latin America. 2008: 1-3.

[13] P Thakur, AK Singh, SB Singh. Shortfalls of exixting methods for Characterization of Voltage Sags from recoeded waveforms. IEEE 6th int. Conf. on Harmonics and Quality of Power. 2014: 885-889.

[14] G Yalcinkaya, MHJ Bollen. Characterization of voltage sags in industrial distribution systems. IEEE Transactions on Industry Applications. 1998; 34: 2197-2204.

[15] P Thakur, AK Singh, RC Bansal. Novel way for classification and type detection of voltage sag. IET Generation, Transmission, \& Distribution. 2013; 7: 398-404.

[16] L Conrad, K Little, C Grigg. Predicting and Preventing Problems Associated with Remote FaultClearing Voltage Dips. IEEE Transactions on industry applications. 1991; 27: 74-78.

[17] MR Alam, KM Muttaqi, A Bouzerdoum. Characterizing voltage sags and swells using threephase voltage Ellipse parameters. IEEE Transaction on Industry Application. 2015; 51(4): 2780-2790.

[18] V Khadkikar. Enhancing electric power quality using UPQC: A comprehensive overview. IEEE Trans. Power Electron. 2012; 27(5): 2284-2297.

[19] MK Saini, R Kapoor. Classification of power quality events: a review. International Journal of Electrical Power and Energy Systems. 2012; 43: 11-19.

[20] MB Latran, A Teke, T Yoldas. Mitigation of power quality problems using distributed static synchronous compensator: a comprehensive review. IET Power Electronics. 2015; 8(7): 1312-1328.

[21] Y Pal, A Swarup, B Singh. A Review of Compensating Type Custom Power Devices for Power Quality Improvement. int. Conf. on Power System Technology. 2008: 1-8.

[22] AK Kapoor, R Mahanty. A quasi passive filter for power quality improvement. in Proc. IEEE Int. Conf on Ind Technology. 2000; 1: 526-529.

[23] JC Das. Passive filters - potentialities and limitations. IEEE Trans.Ind. Applicat. 2004; 40: 232-241.

[24] M Bou-rabee, CS Chang, D Sutanto, KS Tam. Passive and active harmonic filters for industrial power systems. in Proc. IEEE TENCON. 1991: 222-226.

[25] H Akagi. Trends in active power line conditioners. IEEE Trans. Power Electron. 1994; 9(3): $263-268$.

[26] H Akagi. New trends in active Filters for power conditioning. IEEE Trans. Ind Applcat. 1996; 32: 1312-1322.

[27] B Singh, K Al-Haddad, A Chandra. A review of active filters for power quality improvement. IEEE Trans. Ind. Electron. 1999; 46(5): 960-971.

[28] M El-Habrouk, MK Darwish, P Mehta. Active power filters: A review. IEE Electr. Power Appl. 2000; 147(5): 403-413.

[29] Special issue on active and hybrid filters to enhance electric power quality. IEEE Trans. Ind Electron. 2006. 53: 1949-1949.

[30] B Singh, V Verma, A Chandra, K Al-Haddad. Hybrid filters for power quality improvement. in Proc. IEE on Generation, Transmission and Distribution. 2005; 152: 365-378.

[31] Custom Power-State of the Art Cigre WG14.31. 2000.

[32] ML Crow. Power quality enhancement using custom power devices. IEEE Power and Energy Magazine. 2004; 2: 50.

[33] A Jr Domijan, A Montenegro, AJF Kern, KE Mattern. Custom power devices: an interaction study. IEEE Trans. Power Systems. 2005; 20: 1111-1118.

[34] MD Stump, GJ Keane, FKS Leong. The role of custom power products in enhancing power quality at industrial facilities. in Proc. Conf on Energy Management \& Power Del. 1998: 507-517.

[35] Abdullahi Bala Kunya, Tankut Yalcinoz, Gaddafi Sani Shehu. Voltage sag and swell alleviation in Distribution network using custom power devices: D-STATCOM and DVR. IEEE International power electronics and motion control conference and exposition. Turkey 21-24. 2014. 400-405.

[36] Gupt S, Dixit A, Mishra N, Singh SP. Custom power devices for power quality improvement: A review. Int. J. Res. Eng. Appl. Sci. 2012; 2(2): 1646-1659.

[37] Bilgin HF, Ermis M. Design and implementation of a current-source converter for use in industrial applications of DSTATCOM. IEEE Trans. Power Electron. 2010; 25(8): 1943-1957.

[38] Bilgin HF, Ermis M. Current source converter based STATCOM: operating principles, design and field performance. Electr. Power Syst. Res. 2011; 81: 478-487.

[39] Melin PE, Espinoza JR, Zargari NR, Moran LA, Guzman Jl. A novel multi-level converter ased on current source power cell. IEEE Conf. Power Electronics Special. 2008: 2084-2089.

[40] Dash PP, Kazerani M. A multilevel current-source inverter based grid-connected photovoltaic system. North American Power Symp. 2011: 1-6.

IJEEI Vol. 5, No. 3, September 2017: $207-235$ 
[41] Dash PP, Kazerani M. Harmonic elimination in a multilevel Current-Source Inverter-based gridconnected photovoltaic system. 38th IEEE Annual Conf. Ind. Electronics Society. 2012: 1001-1006.

[42] K Somsai, T Kulworawanichpong. Modeling, Simulation and Control of D-STATCOM using TP/EMTP. 13th Int. Conf. on Harmonics and Quality of Power, 2008: 1-4.

[43] Qi Q, Yu C, Wai CK, Ni Y. Modeling and simulation of a STATCOM system based on 3- level NPC inverter using dynamic phasors. IEEE Power Engineering Society General Meeting. 2004; 2: 15591564.

[44] Hui LI, Hao Zhang, Fei MA, Weihua BAO. Modeling, Control and Simulation of grid connected PV System with D-STATCOM. IEEE International Conference on System Science ang Engineering (ICSSE). July 11-13 2014, China: 27-30.

[45] Hendri Masdi, Norman Mariun, SM Bashi, A Mohamed. Design of a Pototype D-statcom using DSP Controller for Voltage Sag Mitigation. IEEE PEDS. 2005: 569-574.

[46] N Henini, F Benzerafa, A Tlemçani. Design and Simulation of Five-level Inverter based DSTATCOM Using Fuzzy Logic. 6th International Renewable Energy Congress(IREC). 2015: 1-6.

[47] Reddy JGP, Reddy KR. Design and simulation of cascaded H-bridge multilevel inverter based DSTATCOM for compensation of reactive power and harmonics. First Int.Conf. Recent Advanced Information Technology, Dhanbad, 15-17 March 2012: 737-743.

[48] B singh, A Adya, AP Mittal, JRP Gupta. Modeling and control of D-STATCOM for threephase fourwire distribution systems. Ind.Appl.Conf. 2005; 4: 2428-2768.

[49] H Fugita, H Akagi. Voltage-regulation performance of a shunt active filter intended for installation on a power distribution system. IEEE Trans. Power Electron. 2007; 22: 1046-1053.

[50] Arya SR, Singh B, Chandra A, Al-Haddad K. Power factor correction and zero voltage regulation in distribution system using DSTATCOM. IEEE Int. Conf. Power Electronics,Drives, Energy System, Bengaluru. 2012: 1-6.

[51] Mohammad Faisal, Md Shahedul Alam, Md Imam Mahadi Arafat, Md Mizanur Rahman, Sk.Md. Golam. PI Controller and Park's Transformation Based Control of Dynamic Voltage estorer for Voltage Sag Minimization. The 9th International Forum on Strategic Technology (IFOST). October 21-23. 2014: 276-279.

[52] Xueqian Fu, Haoyong Chen, Weike Mo. Dynamic Voltage Restorer Based on Active Hybrid Energy Storage System. Power and Energy Engineering Conf. 2014: 1-4.

[53] Gary W Chang, Min-Fu Shih, Yi-Ying Chen, Yi-Jie Liang. A Hybrid Wavelet Transform and NeuralNetwork-Based Approach for Modelling Dynamic Voltage-Current Characteristics of Electric Arc Furnace. IEEE Transactions on Power Delivery. 2014; 29(2): 815-823.

[54] Pedro Roncero-Sánchez, Enrique Acha, Dynamic Voltage Restorer Based on Flying Capacitor Multilevel Converters Operated by Repetitive Control. IEEE Transactions on Power Delivery. 2009; 24(2): 951-960.

[55] AK Jindal, A Ghosh, A. Joshi. Voltage regulation using dynamic voltage restorer for large frequency variations. in Procd IEEE Power Engineering Society General Meeting. 2005; 1: 850 - 856.

[56] R Strzelecki, G Benysek, J Rusinski, H Debicki. Modeling and experimental investigation of the small UPQC systems. in Proc. Compat. Power Electron. 2005: 223-237.

[57] $\mathrm{M} \mathrm{Hu}, \mathrm{H}$ Chen. Modeling and controlling of unified power quality conditioner. In Proc. Adv. Power Syst. Control, Operation Manage. 2000: 431-435.

[58] S Chen, G Joos. A unified series-parallel deadbeat control technique for an active power quality conditioner with full digital implementation. in Proc. IEEE 36th Ind. Appl. Soc.Annu.Meet. Ind. Appl. Conf. 30 Sep-4 Oct. 2001: 172-178.

[59] LM Landaeta, CA Sepulveda, JR Espinoza, CR Baier. A mixed LQRI/PI based control for threephase UPQCs. in Proc. 32nd Annu. Conf. Ind. Electron. Soc. 2006: 2494-2499.

[60] X Huang, J Liu, H Zhang. A unified compensator design based on instantaneous energy equilibrium model for the DC link voltage control of UPQC. in Proc. Appl. Power Electron. Conf. 2009: 15771582.

[61] Y Rong, CLi H Tang, X Zheng. Output feedback control of single-phase UPQC based on a novel model. IEEE Trans. Power Del. Jul.2009; 24(3): 1586-1597.

[62] J Le, Y Xie, Z Zhi, C Lin. A nonlinear control strategy for UPQC. in Proc. Int. Conf. Electr. Mach. Syst. 2008: 2067-2070.

[63] R Rajasree, S Premalatha. Unified power quality conditioner (UPQC) control using feed forward (FF)/ feedback (FB) controller. in Proc. Int. Conf. Comput., Commun. Electr. Technol. Conf. 2011: 364369.

[64] T. Zhili, Z. Dongjiao. Design of dc voltage controller for UPQC by using its small signal model. in Proc. Electr. Control Eng. 2010: 3572-3575.

[65] A Ghosh, AK Jindal, A Joshi. A unified power quality conditioner for voltage regulation of critical load bus. in Proc. IEEE Power Eng. Society General Meeting. 2004; 1: 471- 476.

[66] Ramchandra Nittala, Alivelu M Parimi, K Uma Rao. Comparing the Performance of IDVR for Mitigating Voltage Sag and Harmonics with VSI and CSI as Its Building Blocks. IEEE Int. Conf. on Signal Processing, Informatics, Communication and Energy Systems. 2015: 1-5. 
[67] Pedro E Melín, José R Espinoza, Luis A Morán, José R Rodriguez, Victor M, Carlos R Baier, Javier A Muñoz. Analysis, Design and Control of a Unified Power-Quality Conditioner Based on a CurrentSource Topology. IEEE Transactions ON Power Delivery. October 2012. 27(4):1727-1735.

[68] Vadirajacharya G Kinhal, Promod Agarwal, Hari Oam Gupta. Performance Investigation of NeuralNetwork-Based Unified Power-Quality Conditioner. IEEE Transactions on Power Delivery. 2011: 26(1): 431-437.

[69] Pedro E Melín, José R. Espinoza, Carlos R Baier, Johan I Guzman, Eduardo E Espinosa. Unified Power Quality Conditioner based on Current Source Converters for Harmonic Mitigation using a Decoupled Control Strategy. 37th Annual Conf.on IEEE Industrial Electronics Society. 2011: 41524157.

[70] Pedro E Melín, José R Espinoza, Javier A Muñoz, Carlos R Baier, Eduardo E Espinosa. Decoupled Control of a Unified Power Quality Conditioner based on a Current Source Topology for Fast AC Mains Disturbance Compensation. IEEE Int. Conf. on Industrial Technology. 2010: 730-736.

[71] V Khadkikar, A Chandra, BN Singh. Generalised single-phase p-q theory for active power filtering: simulation and DSP-based experimental investigation. IET Power Electronics. 2009; 2(1): 67-78.

[72] Gupta R, Ghosh A, Joshi A. Characteristic analysis for multisampled digital implementation of fixedswitching-frequency closed-loop modulation of voltage-source inverter. IEEE Trans. Ind. Electron. 2009; 56(7): 2382-2392.

[73] Gupta R, Ghosh A. Frequency-domain characterization of sliding mode control of an inverter used in DSTATCOM application. IEEE Trans. Circuits Syst. 2006; 53(3): 662-676.

[74] Perera LB, Ledwich G, Ghosh A. Multiple distribution static synchronous compensators for distribution feeder voltage support. IET Gener Transm. Distrib. 2012; 6(4): 285-293.

[75] MEC Brito, LR Limongi, MC Cavalcanti, FAS Neves, GMS Azevedo. A step-dynamic voltage regulator based on cascaded reduced-powerseries transformers. Electric Power Systems Research. 2014; 108: 245- 253.

[76] Parag Kanjiya, Bhim Singh, Ambrish Chandra, Kamal-Al-Haddad. SRF Theory Revisited to Control Self Supported Dynamic Voltage Restorer (DVR) for Unbalanced and Nonlinear loads. IEEE Tranactions on Industry Applications. 2013; 47(5): 2330-2340.

[77] Ramesh K Govindarajan, Pankaj Raghav P, G Saravana Ilango. A Dynamic Voltage Restorer with an Improved PLL for Voltage Sensitive Loads. International Conference on Power, Signals, Controls and Computation (EPSCICON). 8 - 10 January. 2014: 1-6.

[78] Ebrahim Babaei, Mohammad Farhadi Kangarlu, Mehran Sabahi. Compensation of voltage disturbances in distribution systems using single-phase dynamic voltage restorer. Electric Power Systems Research. 2010; 80: 1413-1420.

[79] Ebrahim Babaei, Mohammad Farhadi Kangarlu. Operation and control of dynamic voltage restorer using single-phase direct converter. Energy Conversion and Management. 2011; 52: 2965-2972.

[80] Nisha Prakash, Joffie Jacob, Reshmi V. Comparison of DVR Performance with Sinusoidal and Space Vector PWM Techniques. International Conference on Magnetics, Machines \& Drives (AICERA-2014 iCMMD), pp.1-6.

[81] Hamed Abdollahzadeh, Mostafa Jazaeri,Arash Tavighi. A new fast-converged estimation approach for Dynamic Voltage Restorer (DVR) to compensate voltage sags in waveform distortion condition. Electrical Power and Energy Systems. 2014; 54: 598-60.

[82] Rajeswari R, N Karpagam, S Dhanalakshmi. Analysis of dq0 Based Fuzzy Logic Controller in DVR for Voltage Sag and Harmonic Mitigation. Int Conf. on Green Computing Communication and Electrical Engineering. 2014: 1-6.

[83] Mario González a, Víctor Cárdenas a, Gerardo Espinosa. Advantages of the passivity basedcontrol in dynamic voltage restorers for power quality improvement. Simulation Modelling Practice and Theory. 2014; 42: 221-235.

[84] M Basu, SP Das, GK Dubey. Experimental investigation of performance of a single phase UPQC for voltage sensitive and nonlinear loads. in Proc. 4th IEEE Int. Conf. Power Electron. Drive Syst., Oct. 22-25, 2001, pp. 218-222.

[85] J Prieto, P Salmeron, RS Herrera. A unified power quality conditioner for wide load range: Practical design and experimental results. in Proc. IEEE Russia Power Technol: 2005: 1-7.

[86] V Khadkikar, A Chandra, AO Barry, TD Nguyen. Power quality enhancement utilizing single-phase unified power quality conditioner: Digital signal processor-based experimental validation. IET Power Electron. 2011: 4(3): 323-331.

[87] S Moran. A line voltage regulator/conditioner for harmonic-sensitive load isolation. in Proc. Ind. Appl. Soc. Annu. Meet. Conf. 1989: 947-951.

[88] M Correa, S Chakraborty, G Simoes, A Farret. A single phase high frequency AC microgrid with an unified power quality conditioner. in Proc. IEEE Int. Symp. Ind. Electron. 2003: 956-962.

[89] A Nasiri, A Emadi. Different topologies for single-phase unified power quality conditioners. in Proc. 38th Int. Appl. Soc. Annu. Meet. Ind. Appl. Conf. 2003: 976-981.

[90] A Ghosh, AK Jindal, A Joshi. Inverter control using output feedback for power compensating devices. in Proc. Convergent Technol. Conf. 2003: 48-52.

IJEEI Vol. 5, No. 3, September 2017: $207-235$ 
[91] JR Reyes, JR Espinoza, C Sepulveda. Operating region of single-phase UPQCs. in Proc. Power Electron. Spec. Conf. 2005: 1726-1731.

[92] J Correa, F Farret, M Simoes. Application of a modified singlephase $P-Q$ Theory in the control of shunt and series active filters in a $400 \mathrm{~Hz}$ microgrid. in Proc. Power Electron. Spec. Conf. 2005: 2585-2591.

[93] A Kazemi, M Sarlak, M Barkhordary. An adaptive noise canceling method for singlephase unified power quality conditioner. in Proc. 1st IEEE Conf. Ind. Electron. Appl. 2006: 1-6.

[94] K Vadirajacharya, P Agarwal, HO Gupta. Unified constant frequency integration control of universal power quality conditioner. in Proc. Power Electron. Drive Energy Syst. 2006: 1-5.

[95] S Chakraborty, M Weiss, M Simoes. Distributed intelligent energy management system for a singlephase high-frequency AC microgrid. IEEE Trans. Ind. Electron. 2007; 54(1): 97-109.

[96] R Mastromauro, M Liserre, A Dell'Aquila. Single-phase grid connected photovoltaic systems with power quality conditioner functionality. in Proc. Power Electron. Appl. 2007: 1-11.

[97] Y Rong, C Li, H Tang, X Zheng. Output feedback control of single-phase UPQC based on a novel model. IEEE Trans. Power Del. 2009; 24(3): 1586-1597.

[98] KH Kwan, YC Chu, PL So. Model-based $H-\infty$ control of a unified power quality conditioner. IEEE Trans. Ind. Electron: 56(7): 2493-2504.

[99] H Ryoo, G Rim, T Kim, D Kisek. Digital-controlled single-phase unified power quality conditioner for non-linear and voltage sensitive load. in Proc. 30th Annu. Conf. IEEE Ind. Electron. 2004: 24-29.

[100] BR Lin, CL Huang. Implementation of a shunt-series compensator for nonlinear and voltage sensitive load. in Proc. Power Electron. Motion Control Conf. 2006: 1-5.

[101] R Rajasree, S Premalatha. Unified power quality conditioner (UPQC) control using feed forward (FF)/ feedback (FB) controller. in Proc. Int. Conf. Comput., Commun. Electr. Technol. onf. 2011: 364-369.

[102] Alper Çetin, Muammer Ermis, VSC-Based D-STATCOM with Selective Harmonic Elimination. IEEE Transactions On Industry Applications. 2009; 45(3):1000-1015.

[103] Huann-Keng Chiang, Bor-Ren Lin, Kuan-Wei Wu. Study of dynamic voltage restorer under the abnormal voltage conditions. Int. Conf. on Power Electronics and Drives Systems. 2005: 308- 312.

[104] PS Sensarma, KR Padiyar, V Ramanarayanan. Analysis and Performance Evaluation of a Distribution STATCOM for Compensating Voltage Fluctuations. IEEE Transactions on Power Delivery. 2001; 16(2): 259-263.

[105] Thip Manmek, Chathura P Mudannayake. Real-Time Implementation of Voltage Dip Mitigation using D-STATCOM with Fast Extraction of Instantaneous Symmetrical Components. 7th Int. Conf. on Power Electronics and Drive Systems. 2007: 568-575.

[106] Kenichiro Sano, Masahiro Takasaki. A Transformerless D-STATCOM Based on a Multivoltage Cascade Converter Requiring No DC Sources. IEEE Transactions on Power Electronics. 2012; 27(6): 2783-2796.

[107] Mostafa S Hamad, Mahmoud I Masoud, Khaled H Ahmed, Barry W Williams. A Shunt Active Power Filter for a Medium-Voltage 12-Pulse Current Source Converter Using Open Loop Control Compensation. IEEE Transactions on Industrial Electronics. 2014; 61(11): 5840-5850.

[108] Manoj Badoni, Alka Singh, Bhim Singh. Design and Implementation of Adaptive Neuro-Fuzzy Inference System Based Control Algorithm for Distribution Static Compensator. Electric Power Components and Systems. 2015; 43(15):1741-1751.

[109] Narsa Reddy Tummuru, Mahesh K Mishra, S Srinivas, Multifunctional VSC Controlled Microgrid Using Instantaneous Symmetrical Components Theory. IEEE Transactions on Sustainable Energy. 2014; 5(1): 313-322.

[110] D Mohan Reddy, T Gowrimanohar. Dynamic Performance of Power Quality Improvement Using Multilevel DSTATCOM with DG Application. 2nd International Conference on Current Trends in Engineering and Technology. ICCTET'14: 288-295.

[111] SP Gawande, S Khan, YCCE, Nagpur, MR Ramteke. Voltage Sag Mitigation Using Multilevel Inverter based Distribution Static Compensator (DSTATCOM) in Low Voltage Distribution System. 5th Indian Int. Conf. on Power Electronics. 2012:1-6.

[112] K Anuradha, BP Muni, AD Raj Kumar. Modeling of Electric Arc Furnace \& Control Algorithms for voltage flicker mitigation using DSTATCOM. 6th Int. Conf, on Power Electronics and Motion Control. 2009:1123-1129.

[113] Chengyong Zhao, Xia Zhao. A New Method for Voltage Quality Evaluation Based on p-q-r Theory. Intematlonal Conference on Power system Technology. POWERCON 2004 Singapore. 2004: 11521156.

[114] Guohong Wu, Kazutoshi Chubachi, Chung-Neng Huang, Longyun Kang. An Approach to Voltage Quality Improvement by Introduction of STATCOM for Distribution System with Renewable Power Generations. IEEE PES ISGT ASIA. 2012: 1-6.

[115] Labeeb M, Lathika BS. Design and Analysis of DSTATCOM using SRFT And ANN-Fuzzy Based Control for Power Quality Improvement. Recent Advances in Intelligent Computational Systems. 2011: 274-279. 
[116] MA Mulla, R Chudamani, A Chowdhury. Generalized Instantaneous Power Theory and its Applications to Shunt Active Power Line Conditioners under Balanced and Unbalanced Load Conditions. 11th Int. Conf. on Environment and Electrical Engineering, 2012 IEEE: 413-418.

[117] Deepika Masand, Shailendra Jain, Gayatri Agnihotri. Control Strategies for Distribution Static Compensator for Power Quality Improvement. IETE JOURNAL OF RESEARCH. 2008; 54(6): 421428.

[118] Bhim Singh, Sabha Raj Arya. Back-Propagation Control Algorithm for Power Quality Improvement using DSTATCOM. IEEE Transactions on Industrial Electronics. 2013; 61(3): 1-9.

[119] Hyosung Kim, Sang-Joon Lee, Seung-Ki Sul. A Calculation for the Compensation Voltages in Dynamic Voltage Restorers by use of PQR Power Theory. 2004 Applied Power Electronics Conf. and Exposition. 2004: 573-579.

[120] Po-Tai Chengt, Chian-Chung, Huangt Chun-Chiang, Pant Subhashish Bhattacharya. Design and implementation of a series voltage sag compensator under practical utility conditions. 7th Annual Applied Power Electronics Conf. and Exposition, 2002: 1061-1067.

[121] Xiaoqing Han, Ruifen Cheng, Peng Wang, Yanbing Jia. Advanced Dynamic Voltage Restorer To Improve Power Quality In Microgrid. Power and Energy Society General meeting. 2013: 1-5.

[122] Abdul Mannan Rauf, Vinod Khadkikar. Integrated Photovoltaic and Dynamic Voltage Restorer System Configuration. IEEE Transactions on Sustainable Energy. 2015; 6(2 ): 1 - 11 .

[123] Abdul Mannan Rauf, Vinod Khadkikar. An Enhanced Voltage Sag Compensation Scheme for Dynamic Voltage Restorer. IEEE Transactions on Industrial Electronics. 2015; 62(5): 2683-2692.

[124] Marcelo C Cavalcanti, Leonardo R Limongi, Marcio DB Gomes, Gustavo MS Azevedo, Luiz GB Genu. Eight-Switch Power Conditioner for Current Harmonic Compensation and Voltage Sag Mitigation. IEEE Transactions on Industrial Electronics, 2015; 62(8): 4655-4664.

[125] SF Taghizadeh, Nadia Mei Lin Tan, B Nikouei, MAA Younis. Dynamic Voltage Restorer Using the Combination of Fuzzy Logic and EPLL Control Strategies: An Optimized Implementation. 2014 IEEE Innovative Smart Grid Technologies - Asia (ISGT ASIA): 554-559.

[126] MI Marei, MMA Salama. Advanced Techniques for Voltage Flicker Mitigation. 10th Int. Power Electronics Congress. 2006: 1-5.

[127] RA Kantaria, SK Joshi, KR Siddhapura. A Novel Technique for Mitigation of Voltage Sag/Swell by Dynamic Voltage Restorer (DVR). Int. Conf. on Electro/Information Technology. 2010: 1-4.

[128] CK Sundarabalan, K Selvi. Compensation of voltage disturbances using PEMFC supported Dynamic Voltage Restorer. Electrical Power and Energy Systems. 2015; 71: 77-92.

[129] Hojjat Daghani, Reza Ghazi, Hadi Ghasemabadi. Compensating of voltage flicker and disturbance using Dynamic Voltage Restorer based on matrix converter. 21st Iranian Conf. on Electrical Engineering. 2013: 1-6.

[130] N Pavan Kumar, Yash Pal. Performance evaluation of Three-Phase, Three wire DVR for Power Quality Improvement. Student Conf. on Engineering and Systems. 2014: 1-6.

[131] D Graovac, V Katic, A Rufer. Power quality compensation using universal power quality conditioning system. IEEE Power Eng. Rev. 2000; 20(12): 58-60.

[132] Y Chen, X Zha, J Wang, H Liu, J Sun, H Tang. Unified power quality conditioner (UPQC): The theory, modeling and application. in Proc. Int. Conf. Power Syst. Technol. 2000: 1329-1333.

[133] A Elnady, A Goauda, MMA Salama. Unified power quality conditioner with a novel control algorithm based on wavelet transform. in Proc. Can. Conf. Electr. Comput. Eng. 2001: 1041-1045.

[134] BS Chae, WC Lee, DS Hyun, TK Lee. An overcurrent protection scheme for series active compensators. in Proc. 27th Annu. Conf. IEEE Ind. Electron. Soc. 2001: 1509-1514.

[135] P Rodriguez, L Sainz, J Bergas. Synchronous double reference frame PLL applied to a unified power quality conditioner. in Proc. 10th Int. Conf. Harmonics Quality Power: 614-619.

[136] MT Haque, T Ise, SH Hosseini. A novel control strategy for unified power quality conditioner (UPQC). in Proc. Power Electron. Spec. Conf. 2002; 1: 94-98.

[137] G Jianjun, X Dianguo, L Hankui, G Maozhong. Unified power quality conditioner(UPQC): The principle, control and application. in Proc. Power Convers. Conf. 2002: 80-85.

[138] LH Tey, PL So, YC Chu. Neural network-controlled unified power quality conditioner for system harmonics compensation. in Proc. IEEE/PES Transmiss. Distrib. Conf. Exhib. 2002: 1038-1043.

[139] LFC Monteiro, M Aredes, JA Moor Neto. A control strategy for unified power quality conditioner. in Proc. Int. Symp. Ind. Electron. 2003: 391-396.

[140] J Liu, Y He, Y Ye, X Wang. An unified scheme and respective algorithms for the control of DC-linked double converters in an universal power quality controller. in Proc. PowerElectron. Spec. Conf. 2003: 327-332.

[141] P Zhu, X Li, Y Kang, J Chen. A novel control scheme in 2-phase unified power quality conditioner. in Proc. 29th Annu. Conf. IEEE Ind. Electron. Soc. 2003: 16917-1622.

[142] A Esfandiari, M Parniani, H Mokhtari. Mitigation of electric arc furnace disturbances using the unified power quality conditioner. in Proc. 30th Annu. Conf. Ind. Electron. Soc. 2004: 1469-1474.

IJEEI Vol. 5, No. 3, September 2017 : $207-235$ 
[143] M Khoor, M Machmoum. Simplified analogical control of a unified power quality conditioner. in Proc. Power Electron. Spec. Conf. 2005: 2565-2570.

[144] M Aredes, JA Moor, JC Ferreira, LF Monteiro, RM Fernandes, MJ Siqueira. A simplified control strategy for a unified power quality conditioner prototype. in Proc. Power Electron. Spec. Conf. 2005: 2592-2597.

[145] K Kwan, P So, Y Chu. Unified power quality conditioner for improving power quality using MVR with Kalman filters. in Proc. 7t h Int. Power Eng. Conf. 2005: 980-985.

[146] R Strzelecki, J Rusinski, M Jarnut. Properties, simulation and experimental investigation of the series-parallel active power filters. in Proc. Eur. Conf. Power Electron. 2005: 1-9.

[147] S Hongchun, L Zuquan, Y Jilai, X Liang. A novel control strategy for UPQC. in Proc. Transmiss. Distrib. Conf. Exhib. 2005: 1-6.

[148] B Han, B Bae, H Kim, S Baek. Combined operation of unified power-quality conditioner with distributed generation. IEEE Trans. Power Del. 2006; 21(1): 330-338.

[149] V Khadkikar, A Chandra, A Barry, T Nguyen. Application of UPQC to protect a sensitive load on a polluted distribution network. in Proc. Power Eng. Soc. Gen. Meet. 2006: 1-6.

[150] MR Banaei, SH Hosseini. Mitigation of current harmonic using adaptive neural networkwith active power line conditioner. in Proc. IEEE 5th Int. Conf. Power Electron. Motion Control conf. 2006: 1-5.

[151] NG Jayanti, M Basu, MF Conlon, K Gaughan. Optimising the rating of the UPQC for applying to the fault ride through enhancement of wind generation. in Proc. 41st Int. Univ. Power Eng. Conf. 2006: 123-127.

[152] A Kazemi, A Mokhtarpour, M Haque. A new control strategy for unified power quality conditioner (UPQC) in distribution systems. in Proc. Int. Conf. Power Syst. Technol. 2006: 1-5.

[153] RS Kumar, $\mathrm{P}$ Ganesan. 250 kVA unified power quality controller. in Proc. TENCON. 2006: 1-4.

[154] H Zhang, J Liu, X Huang, Z Wang. Design of a new DC link voltage controller for universal power quality controllers. in Proc. Appl. Power Electron. 2007: 473-477.

[155] J Turunen, H Tuusa. Improvement of the voltage compensation performance of the series active power filter using a simple Pl-control method. in Proc. Eur. Power Electron. Appl. 2007: 1-9.

[156] I Axente, M Basu, M Conlon. A control approach for UPQC connected to weak supply point. in Proc. 42nd Int. Univ. Power Eng.Conf. 2007: 619-623.

[157] L Zuquan, S Hongchun. A novel PIXD $\mu$ controller and its application in UPQC DC voltage control. in Proc. 3rd Int. Conf. Electr. Utility Deregulation Restruct. Power Technol. 2008: 1859-1862.

[158] H Djeghloud, H Benalla, A Bentounsi. Supply current and load voltage distortions suppression using the unified power quality conditioner. in Proc. Syst., Signals Devices. 2008: 1-6.

[159] V Khadkikar, A Chandra. A new control philosophy for a unified power quality conditioner (UPQC) to coordinate load-reactive power demand between shunt and series inverters. IEEE Trans. Power Del. 2008: 23(4): 2522-2534.

[160] NG Jayanti, M Basu, K Gaughan, MF Conlon. A new configuration and control of doubly fed induction generator (UPQC-WG). in Proc. 34th Annu. Conf. IEEE Ind.Electron. 2008: 2094-2099.

[161] F Mekri, M Machmoum, NA Ahmed, B Mazari. A fuzzy hysteresis voltage and current control of an unified power quality conditioner. in Proc. 34th Annu. Conf. IEEE Ind. Electron. 2008: 2684-2689.

[162] M Davari, SM Ale-Emran, H Yazdanpanahi, GB Gharehpetian. Modeling the combination of UPQC and photovoltaic arrays with multiinput single-output DC-DC converter. in Proc. Power Syst. Conf. Expo. 2009: 1-7.

[163] H Shen, J Wan, C Yuan, Y Liu, G Li. Harmonic signal detection algorithm in parallel of UPQC studies based on PSO-FUZZY. in Proc. Asia-Pacific Power Energy Eng. Conf. 2007: 1-4.

[164] P Javanbakht, M Abedi. The enhancement of transient performance of cascaded induction motors using UPQC. in Proc. IEEE Int. Electr. Mach. Drives Conf. 2009: 405-412.

[165] SMR Rafiei, R Asadi, G Griva, R Bojoi. Optimal unified power quality conditioner with improved compensation performance under distorted voltages. in Proc. IEEE Bucharest PowerTech. 2009: 18.

[166] M Aredes, RM Fernandes. A dual topology of unified power quality conditioner: The iUPQC. in Proc. 13th Eur. Conf. Power Electron.Appl. 2009: 1-10.

[167] A Vahabzadeh, H Vadizadeh, FA AsI, F Kadkhoda. Use of unified power quality conditioner in Khoozestan-Iran steel complex network, a case study. in Proc. 31st Int.Telecommun. Energy Conf. 2009: 1-6.

[168] AH Moghadasi, H Heydari, M Salehifar. Reduction in VA rating of the unified power quality conditioner with superconducting fault current limiters. in Proc. 1st Power Electron. Drive Syst. 2010: 382-387.

[169] I Axente, JN Ganesh, M Basu, MF Conlon, K Gaughan. A 12-kVA DSP-controlled laboratory prototype UPQC capable of mitigating unbalance in source voltage and load current. IEEE Trans. Power Electron. 2010; 25(6): 1471-1479.

[170] N Sakai, T Ohnishi. Series-shunt power quality compensator by phase follow-up inverter control. in Proc. IEEE Int. Power Electron.Conf. 2010: 1281-1286. 
[171] I Axente, M Basu, MF Conlon, K Gaughan. Protection of unified power quality conditioner against the load side short circuits. IET Power Electron. 2010; 3(4): 542-551.

[172] S Srinath, MP Selvan, K Vinothkumar. Comparative evaluation of performance of different control strategies on UPQC connected distribution system. in Proc. Int. conf.Ind.Inf. Syst. 2010: 502-507.

[173] A Moghadasi, SM Torabi, M Salehifar. Performance evaluation of unified power quality conditioner with SMES. in Proc. Power Quality Conf. 2010: 1-6.

[174] AE Leon, SJ Amodeo, JA Solsona, MI Valla. Non-linear optimal controller for unified power quality conditioners. IET Power Electron. 2011; 4(4): 435-446.

[175] V Khadkikar, A Chandra, A Barry, T Nguyen. Analysis of power flow in UPQC during voltage sag and swell conditions for selection of device ratings. in Proc. Can. Conf. Electr. Comput. Eng. 2006: 867872.

[176] V Khadkikar, A Chandra, A Barry, T Nguyen. Conceptual study of unified power quality conditioner (UPQC). in Proc. IEEE Int. Symp. Ind. Electron. 2006: 1088-1093.

[177] V Khadkikar, A Chandra. A novel control approach for unified power quality conditioner $Q$ without active power injection for voltage sag compensation. in Proc. IEEE Int. Conf. Ind. Technol. 2006: 779-784.

[178] M Yun, W Lee, I Suh, D Hyun. A new control scheme of unified power quality compensator- $Q$ with minimum power injection. in Proc. 30th Annu. Conf. IEEE Ind.Electron.Soc. 2004: 51-56.

[179] WC Lee, DM Lee, TK Le. New control scheme for a unified power-quality compensator-Q with minimum active power injection. IEEE Trans. Power Del. 2010; 25(2): 1068-1076.

[180] Herrera RS, Salmeron P. Instantaneous reactive power theory: A reference in the nonlinear loads compensation. IEEE Trans. Ind. Electron. 2009; 56(6): 2015-2022.

[181] Hyosung K, Blaabjerg F, Bak-Jensen B, Jaeho C. Instantaneous power compensation in three-phase systems by using p-q-r theory. IEEE Trans. Power Electron. 2002; 17(5): 701-710.

[182] Kummari NK, Singh AK, Kumar P. Comparative evaluation of DSTATCOM control algorithms for load compensation. 15th IEEE Conf. Harmonics and Quality of Power. 2012: 299-306.

[183] Chang GW, Shee TC. A novel reference compensation current strategy for shunt active power filter control. IEEE Trans. Power Deliv. 2004; 19(4): 1751-1758.

[184] Mahesh K Mishra, K Karthikeyan. A Fast-Acting DC-Link Voltage Controller for Three-Phase DSTATCOM to Compensate AC and DC Loads. IEEE Transactions on Power Delivery. October 2009; 24(4): 2291-2299.

[185] Arindam Ghosh, Gerard Ledwich. Load Compensating DSTATCOM in Weak AC systems. IEEE Transactions on Power Delivery. 2003; 18(4): 1302-1309.

[186] Juan Segundo-Ramirez, Aurelio Medina, Arindam Ghosh, Gerard Ledwich. Stability Analysis Based on Bifurcation Theory of the DSTATCOM Operating in Current Control. IEEE Transactions on Power Delivery. 2009; 24(3): 1670-1678.

[187] Farhad Shahnia, Arindam Ghosh, Gerard Ledwich, Firuz Zare. Voltage unbalance improvement in low voltage residential feeders with rooftop PVs using custom power devices. Electrical Power and Energy Systems. 2014; 55: 362-377.

[188] Tejas Zaveri, Bhavesh Bhalja, Naimish Zaveri. Comparison of control strategies for DSTATCOM in three-phase, four-wire distribution system for power quality improvement under various source voltage and load conditions. Electrical Power and Energy Systems. 2012; 43: 582-594.

[189] Pradeep Kumar, Niranjan Kumar, AK Akella. A simulation based case study for control of DSTATCOM. ISA Transactions. 2014; 53: 767-775.

[190] Bhim Singh, P Jayaprakash, DP Kothari. Three Single-Phase Voltage Source Converter Based Three-phase four wire DSTATCOM. Third International Conference on Power Systems. 2009: 1-5.

[191] S Chen, G Joos. Rating issues of unified power quality conditioners for load bus voltage control in distribution systems. in Proc. Power Eng. Soc. Winter Meet. 2001: 944-949.

[192] F Ng, MC Wong, YD Han. Analysis and control of UPQC and its DC-link power by use of $p-q-r$ instantaneous power theory. in Proc. Power Electron. Syst. Appl. 2004: 43-53.

[193] A Moghadasi, SM Torabi, M Salehifar. Performance evaluation of unified power quality conditionerwith SMES. in Proc. Power Quality Conf. 2010: 1-6.

[194] D Sreenivasarao, Pramod Agarwal, Biswarup Das. Neutral current compensation in three-phase, four-wire systems: A review. Electric Power Systems Research. 2012; 86: 170-180.

[195] Karanki SB, Geddada N, Mishra MK, Kumar BK. A DSTATCOM topology with reduced DC-Link voltage rating for load compensation with non-stiff source. IEEE Trans. PowerElectron. 2012; 27(3):1201-1211.

[196] Shukla A, Ghosh A, Joshi A. Control schemes for DC capacitor voltages equalization in diodeclamped multilevel inverter-based DSTATCOM. IEEE Trans. Power Deliv. 2008; 23(2): 1139-1149.

[197] Kumar C, Mishra MK. A modified DSTATCOM topology with reduced VSI rating, DC link voltage, and filter size. Int. Conf. Clean Electrical Power. 2013: 325-331.

[198] Srikanthan S, Mishra MK, Rao RKV. Improved hysteresis current control of three-level inverter for distribution static compensator application. IET Power Electron. 2009; 2(5): 517-526.

IJEEI Vol. 5, No. 3, September 2017: $207-235$ 
[199] lyer S, Ghosh A, Joshi A. Inverter topologies for DSTATCOM applications-a simulation study. Electr. Power Syst. Res. 2005; 75: 161-170.

[200] Mahesh K Mishra, Arindam Ghosh, Avinash Joshi, Hiralal M. Suryawanshi, A Novel Method of Load Compensation Under Unbalanced and Distorted Voltages. IEEE Transactions on Power Delivery. 2007; 22(1): 288-295.

[201] S Srikanthan, Mahesh Kumar Mishra. DC Capacitor Voltage Equalization in NeutralClamped Inverters for DSTATCOM Application. IEEE Transactions on Industrial Electronics. 2010; 57(8): 2768-2775.

[202] Maryam Saeedifard, Hassan Nikkhajoei, Reza Iravani. A Space Vector Modulated STATCOM Based on a Three-Level Neutral Point Clamped Converter. IEEE Transactions on Power Delivery. 2007; 22(2): 1029-1039.

[203] M Kesler, E Ozdemir. A novel control method for unified power quality conditioner(UPQC) under nonideal mains voltage and unbalanced load conditions. in Proc. Appl. Power Electron. Conf. 2010: 374379.

[204] GS Kumar, BK Kumar, MM Kumar. Optimal VA loading of UPQC during mitigation of unbalanced voltage sags with phase jumps in three-phase four-wire distribution system. in Proc. Int. Conf. Power Syst. Technol. 2010: 1-8.

[205] T Zhili, L Xun, C Jian, K Yong, Z Yang. A new control strategy of UPQC in three-phase four-wire system. in Proc. IEEE Power Electron. Spec. Conf. 2007: 1060-1065.

[206] T Zhili, L Xun, C Jian, K Yong, D Shanxu. A direct control strategy for UPQC in threephase four-wire system. in Proc. Power Electron. Motion Control Conf. 2006:1-5.

[207] X Li, G Zhu, S Duan, J Chen. Control scheme for three-phase four-wire UPQC in a threephase stationary frame. in Proc. 33rd Annu. Conf. IEEE Ind. Electron. Soc. 2007: 1732-1736.

[208] J Prieto, P Salmeron, JR Vazquez, J Alcantara. A series-parallel configuration of active power filters for VAr and harmonic compensation. in Proc. IEEE 28th Annu. Conf. Ind.Electron. Soc: 2945-2950.

[209] D Sreenivasarao, Pramod Agarwal, Biswarup Das. Neutral current compensation in three-phase, four-wire systems: A review. Electric Power Systems Research. 2012; 86: 170- 180.

[210] Jinn-Chang Wu, Hurng-Liahng Jou, Hsin-Hsing Hsaio, Shun-Tian Xiao. A New Hybrid Power Conditioner for Suppressing Harmonics and Neutral-Line Current in Three-Phase Four-Wire Distribution Power Systems. IEEE Transactions on Power Delivery. 2014; 29(4): 1525-1532.

[211] Vincent George, Mahesh K Mishra. Design and Analysis of User-Defined Constant Switching Frequency Current-Control-Based Four-Leg DSTATCOM. IEEE Transactions on Power Electronics. 2009; 24(9): 2148-2158.

[212] Alka Sing. Performance Evaluation of Three Different Configurations of DSTATCOM with Nonlinear Loads. IETE Journal of Research. 2010; 56(6): 313-326.

[213] S Kumar, Bhim Singh. Control of 4-Leg VSC Based DSTATCOM using Modified Instantaneous Symmetrical Component Theory. Third International Conference on Power Systems. 2009: 1-6.

[214] B Singh, P Jayaprakash, DP Kothari. New control approach for capacitor supported DSTATCOM in three-phase four wire distribution system under non-ideal supply voltage conditions based on synchronous reference frame theory. Electrical Power and Energy Systems; 33: 1109-1117.

[215] G Chen, Y Chen, KM Smedley. Three-phase four-leg active power quality conditioner without references calculation. in Proc. Appl. Power Electron. Conf. 2004: 587-593.

[216] V Khadkikar, A Chandra. A novel structure for three-phase four wire distribution system utilizing unified power quality conditioner (UPQC). IEEE Trans. Ind. Appl. 2009; 45(5): 1897-1902.

[217] Y Pal, A Swarup, B Singh. A comparative analysis of three-phase four-wire UPQC topologies. in Proc. Int. Conf. Power Electron. Drives Energy Syst. 2010: 1-6.

[218] Lu X, lyer KLV, Mukherjee K, Kar NC. A wavelet/PSO based voltage regulation scheme and suitability analysis of copper and aluminum-rotor induction machines for distributed wind power generation. IEEE Trans. Smart Grid. 2012; 3(4): 1923-1934.

[219] M Prasad, AK Akella. Performance evaluation of three different inverter configurations of DVR for mitigation of voltage events. Indonesian Journal of Electrical Engineering and Informatics, 2016; 4(4): 225-239.

[220] SA Gawish, SM Sharaf, MS El-Harony. Voltage Stabilization of a wind turbine with STATCOM using intelligent control techniques. Indonesian Journal of Electrical Engineering and Informatics, 2016; 4(1): 24-34. 